Scholarship Repository

University of Minnesota Law School

Articles

Faculty Scholarship

2007

\title{
The Goldilocks Hypothesis: Balancing Intellectual Property Rights at the Boundary of the Firm
}

\author{
Dan L. Burk \\ UC Irvine School of Law, dburk@law.uci.edu \\ Brett McDonnell \\ University of Minnesota Law School, bhm@umn.edu
}

Follow this and additional works at: https://scholarship.law.umn.edu/faculty_articles

Part of the Law Commons

\section{Recommended Citation}

Dan L. Burk and Brett McDonnell, The Goldilocks Hypothesis: Balancing Intellectual Property Rights at the Boundary of the Firm, 2007 U. ILL. L. REV. 575 (2007), available at https://scholarship.law.umn.edu/ faculty_articles/177.

This Article is brought to you for free and open access by the University of Minnesota Law School. It has been accepted for inclusion in the Faculty Scholarship collection by an authorized administrator of the Scholarship Repository. For more information, please contact lenzx009@umn.edu. 


\title{
THE GOLDILOCKS HYPOTHESIS: BALANCING INTELLECTUAL PROPERTY RIGHTS AT THE BOUNDARY OF THE FIRM ${ }^{\dagger}$
}

Dan L. Burk*

Brett H. McDonnell**

\begin{abstract}
Recent scholarship has begun to assess the role of intellectual property rights in the theory of the Coasean firm. Some of this scholarship has looked at the effects of intellectual property on decisions to "make or buy" inputs to production. Other scholarship has looked at the effects of intellectual property on allocation of resources between employees and the firm. In this article, we integrate these two lines of scholarship, positing a "Goldilocks hypothesis" for the proper disposition of intellectual property rights. We argue that to properly allocate resources within the firm, property rights must be calibrated so as to avoid on the one hand misappropriation of firm resources when rights are inadequate, and on the other hand dissipation of employee incentives when rights are excessive. Similarly, we argue that to properly manage transaction costs at the edge of firms, property rights must be calibrated so as to avoid on the one hand inefficient integration into the firm of specialized functions when property rights are inadequate, and on the other hand a fragmented anticommons of specialty firms when property rights are excessive. Thus, we conclude that in order to contribute to the efficient structure of firms, intellectual property rights can be neither too weak nor too strong, but must be constituted "just right."
\end{abstract}

\section{INTRODUCTION}

Modern economic theories of the firm have developed to consider how hierarchical firms serve to lower the cost of transactions that would

$\dagger$ Copyright 2006 by Dan L. Burk and Brett H. McDonnell.

* Oppenheimer Wolff \& Donnelly Professor of Law, University of Minnesota. The authors thank Tom Cotter, Yochai Benkler, David McGowan, Robert Suggs, Manuel Utset, and participants in the Yale Information Society Project speaker series for helpful comments on a previous draft of the article.

** Professor of Law, University of Minnesota. 
be prohibitively high if undertaken in the marketplace. Firms exist, it is argued, because some production functions are better performed without costly negotiations, and the decision whether to make a given input or to buy it from another in the market will depend on the relative transaction costs of each option. Law and economics scholarship has adopted the theory of the firm to describe how the law may help lower transaction costs both within firms and between firms, guiding parties to the lowest cost solutions. Such cost-lowering legal mechanisms include laws governing the fiduciary duties of managers and employees, laws facilitating contracts, and laws establishing default rules, such as property rights, for those occasions when contracts fail to foresee and provide for disputes. Property law in particular has become important in modern theories of the firm, as property rights both facilitate exchanges between firms and secure assets within firms.

Among the most important assets of the modern firm are intellectual properties in a variety of legal forms, including patents, copyrights, trade secrets, and trademarks. Recent scholarship has begun to explore the role that the law governing such intellectual property plays in defining the nature of the firm. In one recent study, Oren Bar-Gill and Gideon Parchomovsky have argued that strong intellectual property rights, of the sort conferred by the patent system, are important to defining the boundary between the firm and the market. ${ }^{1}$ Robert Merges has similarly suggested that strong intellectual property rights will foster the development of smaller, innovative firms, ${ }^{2}$ and together with Ashish Arora, he has developed a model illustrating such a scenario. ${ }^{3}$

At the same time, research in a different direction has addressed the effect of intellectual property on transaction costs within the firm. One of us (Burk) has, in previous work, suggested that the structure of intellectual property law generally reflects and supports property-based theories of the firm as those theories relate to the disposition of assets within the firm. ${ }^{4}$ Burk argues that many aspects of intellectual property law help define the allocation of creative works between employer and employee, consonant with an agency-based and property-based view of the firm. ${ }^{5}$ In a similar vein, Paul Heald has argued that patents can help ameliorate problems of team production and asset partitioning within the

1. See Oren Bar-Gill \& Gideon Parchomovsky, Intellectual Property Law and the Boundaries of the Firm (June 24, 2004) (unpublished manuscript) (on file with the University of Pennsylvania Law School), available at $\mathrm{http}: / / \mathrm{ssrn}$.com/abstract $=559195$.

2. See Robert P. Merges, A Transactional View of Property Rights, 20 BERKELEY TECH. L.J. 1477 (2005) [hereinafter Merges, Transactional View]; see also Robert P. Merges, Intellectual Property Rights, Input Markets, and the Value of Intangible Assets (Feb. 9, 1999), http://www.law.berkeley. edu/institutes/bclt/pubs/merges/iprights.pdf [hereinafter Merges, Intangible Assets].

3. See Ashish Arora \& Robert P. Merges, Specialized Supply Firms, Property Rights, and Firm Boundaries, 13 INDUS. \& CORP. CHANGE 451 (2004).

4. Dan L. Burk, Intellectual Property and the Firm, 71 U. CHI. L. REV. 3 (2004).

5. Id. at $13-14,17-18$. 
firm. ${ }^{6}$ In related work, Robert Merges has argued that legal rules assigning the rights in employee inventions to employers make economic sense. ${ }^{7}$

These two complementary lines of scholarship appear to converge at the boundary of the firm, illuminating the role of intellectual property as it applies, respectively, to interfirm and intrafirm transactions. In this article, we consider the role of intellectual property rights in both of these contexts, integrating these bodies of scholarship as they define the boundary of the firm from the inside out, as well as from the outside in. We argue that in each situation, defining and allocating intellectual property rights plays an important role in demarcating the boundary of the firm. In particular, we argue that intellectual property rights that are improperly calibrated, that are either too strong or too weak, will lead to inefficient firm and market structures.

The argument for strong property rights is largely apparent from the two lines of previous scholarship; where transaction costs might deter outsourcing to specialty suppliers, property rights will assist the consummation of such transactions. At the same time, strong property rights that allocate residual interest in intellectual property within firms will prevent employees from walking away with the firm's assets. But we argue that this insight must be balanced against the hazards of property rights that are too strong. Overly strong property rights potentially threaten to create an "anticommons" of firms blocking each others' innovations, and in response, firms may integrate into inefficiently large firms that internalize the problem created by excessive property protection. Similarly, inefficiently strong residual intellectual property rights may hamper employee mobility and creativity, making it difficult for firms to attract and retain quality employees. Thus, we posit a "Goldilocks hypothesis" for intellectual property rights and the firm: like the size of a chair, the temperature of a porridge, or the firmness of a mattress, the provision of intellectual property rights should not vary too far to one extreme or another, but must be calibrated so that it is "just right."

We begin by reviewing the development of the theory of the firm and the recent work examining intellectual property in light of theories of the firm, particularly transaction cost economics and general property rights theory. We describe current scholarship that considers the effect of intellectual property on interfirm and intrafirm transactions, both critiquing and expanding on the insights in this literature. We then move to

6. See Paul Heald, A Transactions Cost Theory of Patent Law, 66 OHIO ST. L.J. 473 (2005).

7. See Robert P. Merges, The Law and Economics of Employee Inventions, 13 HARV. J.L. \& TECH. 1 (1999).

8. See Peter \& IONA OpIE, The Classic Fairy TAles 199 (1974). The character "Goldilocks" is a relative newcomer to this English folktale, first appearing in the early twentieth century; in the oldest recorded versions, the intruder into the house of the Three Bears is a disreputable old woman who tastes their porridge, sits in their chairs, and sleeps in their beds. Id. at 199-200. 
a discussion of how these lines of scholarship may be integrated around a "Goldilocks hypothesis" of intellectual property that is neither too strong nor too weak, but "just right." We conclude with several observations regarding the implications of our synthesis and suggest several lines of future research that might naturally flow from our framework.

\section{INTELLECTUAL PROPERTY AND THE FIRM}

Intellectual property covers a wide range of subject matter: inventions, poems, computer programs, chemical molecules, client lists, goodwill and firm reputation, business methods, databases, genomes. These and many other informational entities can be covered by some form of intellectual property right. As modern economies shift to high technology manufacturing, service industries, and generation of intangible products, the importance of business assets rooted in intellectual property has grown. Thus, the theory of the firm, which attempts to explain the structure and nature of business organizations, needs to account for the disposition of these important intangible assets. In turn, theories explaining intellectual property perhaps need to more carefully contemplate the role of firms. In this Part, we briefly review the fundamentals of the theory of the firm and the nascent literature that has begun to address intellectual property in terms of such theories.

\section{A. The Theory of the Firm}

Ronald Coase launched the modern theory of the firm in 1937 with his germinal paper on "The Nature of the Firm." Coase explored the basic question of why some production functions are executed within a firm while others are executed between firms. ${ }^{10}$ Sometimes firms choose to make a product or develop a capability internally, and other times firms choose to buy expertise or products in the marketplace. ${ }^{11}$ What determines this choice? In other words, Coase asked, what accounts for the boundary of firms? Why are they the size they are, and not larger or smaller? Indeed, why do we need activity carried on within firms at all, given the efficiencies that economists generally associate with market transactions?

Coase pointed to transaction costs as the guiding explanation for the nature of firms. ${ }^{12}$ There are a variety of costs generated when two firms enter into a transaction with each other. Imagine making a product, say that old standby example of a widget, that involves using two different assets $A$ and $B$, and suppose that two different parties own those

9. Ronald H. Coase, The Nature of the Firm, 4 ECONOMICA 386 (1937). Early work by Knight addresses similar questions. See F. H. KNIGHT, RISK, UNCERTAINTY, AND PROFIT (1921).

10. See Coase, supra note 9, at 393-94.

11. See id. at 394-96.

12. See id. at $395-96$. 
assets. The owners of $A$ and $B$ may enter into a contract governing the making of the widget, but they face many costs. First, they must search for and identify each other as potential partners. Once they have found each other, they must negotiate with each other as to the terms that will govern their relationship in making the widget. Once they have reached agreement and entered into a contract, each party must monitor the performance of the other to ensure that it is doing as promised. Disputes may arise as to whether one or both has performed as promised. Each of these steps may generate costs that reduce the value that the transaction creates. ${ }^{13}$

Many of those costs can be avoided by bringing a transaction within a firm, in which authorized agents execute decisions within a hierarchical organization. This structure largely eliminates the costs associated with search and identification because the production functions associated with making the widget will be performed by known actors within the firm. Negotiation costs are also curtailed because the parameters of the manufacturing relationship are specified by executive fiat rather than by bargaining. ${ }^{14}$ Performance monitoring costs are eliminated or curtailed because of the alignment of interests within the firm; presumably actors within the same firm have similar motivations not to defect from the project. At a minimum, less costly nonlegal sanctions - such as termination of employment-can be brought to bear as a threat for failure or noncompliance of performance.

However, the firm faces its own set of transaction costs. Although the motivations of actors within a firm tend to be more aligned than those of separate firms, firms still face problems of both coordination and motivation. Consider again our widget makers, and suppose now that one firm owns both assets $A$ and $B$. The interfirm costs described above are no longer relevant. However, someone must coordinate the activities involved in making the widgets. This involves identifying what must be done and communicating instructions to the different employees doing the tasks. Moreover, both managers and employees may not be properly motivated to do what is best for the firm. If they can, they may try to divert firm resources to themselves. Or, they may simply want to shirk and not work very hard. Of course, the firm can try to detect and punish such misbehavior, or give employees and managers incentives to pursue the firm's best interests, but all such devices themselves involve costs. ${ }^{15}$

Thus, both interfirm and intrafirm transactions involve their own set of costs. Note that all of these transaction costs, both interfirm and intrafirm, arise from the unavoidable fact of incomplete and asymmetric

13. See Robert COOTER \& ThOMAs Ulen, LAW AND ECONOMics 91-95 (4th ed. 2004).

14. See Coase, supra note 9, at 391-92.

15. The classic early pieces on how firms handle such agency costs are Armen A. Alchian \& Harold Demsetz, Production, Information Costs, and Economic Organization, 62 AM. ECON. REV. 777 (1972), and Michael C. Jensen \& William H. Meckling, The Theory of the Firm: Managerial Behavior, Agency Costs, and Ownership Structure, 3 J. FIN. ECON. 305 (1976). 
information. Coase posited that the activity and size of firms would tend to extend to, but not beyond, the point where overall transaction costs are minimized. ${ }^{16}$ That is, if a transaction can be accomplished at lower cost within one firm than between two different firms, it will be done within one firm, while if the interfirm transaction is cheaper, it will be done between firms. ${ }^{17}$ Evolutionary pressures will tend to reward firms that have appropriate boundaries and punish those that are either too large or too small. ${ }^{18}$

Later writers elaborated upon Coase's basic framework. Oliver Williamson emphasized several key concepts related to the problem of transaction costs. ${ }^{19}$ The fact that contracts are incomplete is crucial to this problem. ${ }^{20}$ Parties could avoid many of the problems identified above if they could write contracts that anticipated all possible future events and dictated how all parties should act for each possibility. ${ }^{21}$ Such contracts are impossibly costly to write for all but the very simplest of transactions, however, and hence contracts will not provide for all contingencies. ${ }^{22}$ Several important insights follow from the reality of incomplete contracting.

First, each party may attempt to benefit at the expense of other parties on the occurrence of events not provided for in the contract. This leads Williamson to consider the problem of "hold-ups." ${ }^{\text {"23 }}$ Parties may make investments in specific assets in anticipation of a transaction. However, once they have begun to perform they may be subject to new or opportunistic demands by their counterparts in the transaction, who recognize that, having made the investment, the performing party may now find it hard to exit the transaction without losing the value of her investment. This is particularly a problem where the value of the investment is much higher within a particular relationship than in other uses, i.e., where the investment's value is asset specific. This threat may discourage people from making valuable asset-specific investments that would

16. See Coase, supra note 9 , at $401-02$.

17. Recent commentary has suggested that communications technology may, in addition to market negotiation and executive fiat, facilitate a third method of self-organizing production. See Yochai Benkler, Coase's Penguin, or Linux and the Nature of the Firm, 112 YALE L.J. 369, 375-78 (2002). However, it is unclear how robust this potential production mechanism will prove. As David McGowan and others have pointed out, the much-touted "open source" example of software production retains all the hallmarks of a Coasean hierarchy. See Dan Burk, Bioinformatics Lessorns from the Open Source Movement, in ETHICS, COMPUTING, AND GENOMICS: MORAL CONTROVERSIES IN COMPuTATIONAL Genomics 247 (Herman T. Tavani ed., 2006); David McGowan, Legal Implications of Open-Source Software, 2001 U. ILL. L. REV. 241, 285-86.

18. See Coase, supra note 9 , at 401-05.

19. See Oliver E. Williamson, THE ECONOMic InSTItUTions of CAPITAlism (1985) [hereinafter Williamson, ECONOMiC Institutions]; Oliver E. Williamson, ThE Mechanisms of GOVERNANCE (1996).

20. See generally WILLIAMSON, ECONOMIC INSTITUTIONS, supra note 19, at 56-57.

21. See generally id.

22. See generally id. at 54 .

23. See id. at 79-80; see also Aaron S. Edlin \& Stefan Reichelstein, Hold-ups, Standard Breach Remedies, and Optimal Investment, 36 AM. ECON. REV. 478, 478 (1996). 
leave them vulnerable to hold-up. Williamson posits that transactions will be structured in ways that reduce the hold-up problem. ${ }^{24}$

As a corollary to this insight, it has been recognized that contracts cannot solve the hold-up problems that may occur within the firm any more than they can solve the problems between firms. Employees, whose interests are not necessarily aligned with those of the firm, are subject to contracts, but an employment contract cannot anticipate every contingency. Thus, employees may have occasion to act opportunistically, diverting firm resources to their own ends, or acting as internal hold-ups in situations that have not been covered by their contract. Some opportunistic activity can be ameliorated by noncontractual mechanisms, such as stock options or bonuses, that reward employees in alignment with the goals of the firm. Thus, duties and relationships within the firm will be structured to reduce internal hold-up problems. ${ }^{25}$

A second important consideration that follows from incomplete contracting is that because contracts do not dictate what parties are supposed to do in all contingencies, very often there will be discretion in deciding how to perform. Someone must decide what to do, and an important aspect of both the contracts between firms and within firms is the allocation of residual decision-making authority. The property rights theory of the firm, developed by Oliver Hart together with Grossman and Moore (GHM), focuses particularly on this residual authority. ${ }^{26}$ If property rights are vested in a firm, those residual rights allow the firm to redeploy assets intended for interfirm bargains if the other party acts opportunistically. ${ }^{27}$ Similarly, residual authority over property allows the firm to control the disposition of assets within the firm if employees act opportunistically. ${ }^{28}$

Corporate law scholarship has begun to integrate the GHM framework, leading to a de-emphasis on the "nexus of contracts" metaphor and a greater focus on hierarchical decision-making authority within the firm - seeing firms as "islands of conscious power." 29 An important recent extension of the GHM literature comes from Raghuram Ragan and

24. See, e.g., WiLLIAMSON, ECONOMIC INSTITUTIONS, supra note 19, at 114-15.

25. For an overview of the transaction cost economics literature, see Howard A. Shelanski, Empirical Research in Transaction Cost Economics: A Review and Assessment, 11 J.L. ECON. \& ORG. 335 (1995).

26. See Oliver D. Hart, Firms, Contracts, And Financial Structure 30 (1995) for an overview. Critical contributions to this literature include Sanford Grossman \& Oliver Hart, The Costs and Benefits of Ownership: A Theory of Vertical and Lateral Integration, 94 J. POL. ECON. 691 (1986); Oliver Hart \& John Moore, Property Rights and the Nature of the Firm, 98 J. POL. ECON. 1119 (1990); Oliver Hart \& John Moore, Incomplete Contracts and Renegotiation, 56 ECONOMETRICA 755 (1988). The authorial combinations of Grossman, Hart, and Moore have led to the acronym "GHM" for property-based theories of the firm.

27. See HART, supra note 26 , at 31-32.

28. See id. at 58.

29. See Edward B. Rock \& Michael L. Wachter, Islands of Conscious Power: Law, Norms, and the Self-Governing Corporation, 149 U. PA. L. REv. 1619, 1638-39 (2001). 
Luigi Zingales. ${ }^{30}$ They analyze how firms structure their internal organization to give employees access to resources that the employees need for their jobs. ${ }^{31}$ They also argue that it may make sense to vest ownership in outside parties with little specific investment in a firm because allocating too much power to insiders may allow them to use that power against other insiders, an idea also explored in earlier work by Bengt Holmstrom. $^{32}$

Margaret Blair and Lynn Stout have built on this work with their team production theory of the firm. ${ }^{33}$ Blair and Stout argue that boards of directors serve as mediating hierarchs coordinating and resolving conflicts between various firm insiders. ${ }^{34}$ The presence of such a neutral, centralized decision maker helps assure the insiders that other insiders will not expropriate available rents, and thereby encourages them to make firm-specific investments. ${ }^{35}$ A question for this theory is whether the directors have adequate incentives to do a good job.

The GHM formulation of the firm also argues that assets that have higher value when used together will tend to be owned within the same firm, as a way of reducing the hold-up problem. ${ }^{36}$ This observation was expanded by David Teece and others under the rubric of "appropriability," that is, conditions necessary for firms to profit from innovation. ${ }^{37}$ Firms will seek to minimize their exposure to hold-up by a variety of appropriability mechanisms, such as by control over complementary assets necessary to deployment of the innovation, or by building trusted relationships that are less likely to result in defection. ${ }^{38}$ Trade secrecy and lead time are also common appropriability mechanisms. ${ }^{39}$ Employment of intellectual property strategies, including patenting, have been recognized as important appropriability mechanisms, ${ }^{40}$ and this recognition has led to a growing scholarship on the role of intellectual property in determining the boundaries of the firm. ${ }^{41}$

30. See Raghuram G. Ragan \& Luigi Zingales, Power in the Theory of the Firm, 113 Q.J. ECON. 387 (1998).

31. See id. at 388 .

32. See Bengt Holmstrom, Moral Hazard in Teams, 13 BELL J. ECON. 324, 325, 339-40 (1982).

33. See Margaret Blair \& Lynn Stout, A Team Production Theory of Corporate Law, 85 VA. L. REV. 247 (2001).

34. Id. at $279-81$.

35. Id.

36. See HART, supra note 26 , at 50 .

37. David J. TeECE, Managing InTEllectual Capital 19 (2000).

38. Id. at $29,59$.

39. David Teece, Profiting from Technological Innovation: Implications for Integration, Collaboration, Licensing and Public Policy, 15 RES. POL'Y 285, 286-87 (1986).

40. Wesley M. Cohen et al., Protecting Their Intellectual Assets: Appropriability Conditions and Why U.S. Manufacturing Firms Patent (Or Not) 3 (Nat'l Bureau of Econ. Research, Working Paper No. 7552, 2000), available at http://www.nber.org/papers/w7552.

41. For more in-depth overviews of the theory of the firm, see PAUL MILGROM \& JOHN Roberts, ECONOMICS, ORGANIZATION AND MANAGEMENT (1992); Oliver Hart, An Economist's Perspective on the Theory of the Firm, 89 COLUM. L. REV. 1757 (1989); Michael J. Meurer, Law, Economics, and the Theory of the Firm, 52 BUFF. L. REV. 727 (2004). 


\section{B. The Role of Intellectual Property}

Despite their centrality to business law and economics, considerations regarding the size, nature, or structure of firms have been largely absent from theories explaining intellectual property, including a striking absence from economic theories of intellectual property. Scholars have identified several possible justifications for intellectual property law, but economic justifications have been predominant. ${ }^{42}$ The traditional focus of intellectual property scholarship has been to analyze incentives to create products of the sort covered by different forms of intellectual property rights. In general, such scholarship has focused on the public good nature of new ideas. ${ }^{43}$ New ideas, as a form of information, are typically nonexhaustible - that is, use by one person does not preclude equal use by anyone else. They are also nonexcludable-once other persons become aware of the idea, it is hard to keep them from being able to use it. $^{44}$ Because the idea is nonexcludable, potential users will be reluctant to pay for new ideas - their optimal strategy is to free-ride, waiting to obtain the idea for free once it has been created. But if everyone waits to obtain the idea for free, no one will make the investment to generate it in the first instance. Consequently, private individuals will generally lack incentives to produce an adequate level of public goods. A key point of intellectual property is to help lessen the public good nature of new ideas by giving creators the ability to legally exclude others from using the ideas.

Invention or creation of new ideas is not the end of the story, however-development and provision of the new idea to the public are equally if not more important. Intellectual property rights have functions even after any given new idea has been created. ${ }^{45}$ The new product must be developed and marketed in order to be useful. Persons other than the original creators of the product will typically be better positioned to do these tasks. The public good nature of intellectual property complicates incentives to develop intellectual products, as those trying to develop a new product may find it hard to stop others from developing the same idea, thereby reducing their own incentive to develop. We thus need to encourage bargaining and coordination between various persons with related assets in developing new products once they have been created. This development may occur in firms other than the creating firm,

42. For a good, brief overview of the main justifications of intellectual property, and an evaluation of its benefits and costs, see Roberto Mazzoleni \& Richard R. Nelson, The Benefits and Costs of Strong Patent Protection: A Contribution to the Current Debate, 27 RES. POL'Y 273 (1998).

43. On public goods, see Paul A. Samuelson, The Pure Theory of Public Expenditure, 36 REV. ECON. \& STAT. 387 (1954).

44. On the public good nature of information, see William M. Landes \& Richard A. Posner, An Economic Analysis of Copyright Law, 18 J. LEGAL STUD. 325 (1989).

45. See Mazzoleni \& Nelson, supra note 42 , at $279-80$. 
or it may be done by different people and groups within the same firm in which the product was created. ${ }^{46}$

Disclosure rationales have also played an important role in the justification of intellectual property, particularly for patent law. One way that developers of valuable information may try to prevent others from using the idea is to hide it. Hiding useful information, though, has social costs, as it prevents others from using the information. There are also actual costs incurred by hiding the information; guards, fences, locks, and passwords are costly. Protecting information by hiding it may result in wasteful investment in secrecy. The law of trade secrecy supplies some legal protection for confidential information, so that the information holder need not overinvest in secrecy, ${ }^{47}$ but the information still remains inaccessible to the public. Thus, another purpose of intellectual property law is to encourage disclosure of useful information by giving the developers of creative works rights over the works, so that even if others learn about them, others can use the works only with the consent of the person who holds the intellectual property right. Indeed, patent law conditions the grant of an intellectual property right upon the explicit disclosure of the claimed invention. ${ }^{48}$

The problem of disclosure to the public leads to questions about disclosure in a more limited context, between parties to a transaction, and ultimately to consideration of intellectual property and the firm. Important elements of a theory regarding intellectual property and the firm can be found in the work of Edmund Kitch, which has long been discussed and debated on other grounds. Early on, Kitch addressed patents in the transactional context. The clearest application of this work is directed to interfirm transactions. Kitch recognized early on that property rights in intangible information serve to solve the "disclosure paradox" recognized by Kenneth Arrow: once the innovator discloses its idea to the would-be developer, there is no reason left for the latter to compensate the former, but before disclosure of the idea, the developer does not know what it is worth. ${ }^{49}$ This creates a potential standoff, in which the innovator is unwilling to disclose without assurances of payment, but the developer is unwilling to give assurances until disclosure. This scenario can be identified as an extreme variation on the hold-up problem in

46. On the role of intellectual property in encouraging development of already-created ideas, see Burk, supra note 4, at 13-14, 18-20; Heald, supra note 6, at 489-91. Burk and Heald point to Edmund Kitch's prospect theory as developing a similar idea. See Edmund Kitch, The Nature and Function of the Patent System, 20 J.L. \& ECON. 265 (1977) [hereinafter Kitch, Nature and Function]; see also Edmund Kitch, The Law and Economics of Rights in Valuable Information, 9 J. LEGAL STUD. 683 (1980) [hereinafter Kitch, Valuable Information] (discussing trade secrecy in the context of the firm).

47. See Dan L. Burk, Misappropriation of Trade Secrets in Biotechnology Licensing, ALB. L.J. SCI. \& TECH. 121, 129 (1994); David Friedman et al., Some Economics of Trade Secret Law, 5 J. ECON. Perspectives 61, 67 (1991).

48. 35 U.S.C. $\S 112(2000)$.

49. See Kenneth J. Arrow, Economic Welfare and the Allocation of Resources for Invention, in THE RATE AND DIRECTION OF INVENTIVE ACTIVITY 609 (Nat'l Bureau of Econ. Research ed., 1962). 
transaction cost economics, where the opportunist is effectively able to misappropriate the value of the asset because the asset is nonexcludable.

The disclosure problem is only slightly ameliorated by the availability of trade secrecy, imposed primarily via contract, tort, or restitution. The developer of an idea might attempt to impose confidentiality or duties of loyalty via contract before agreeing to disclose valuable information and may be unwilling to disclose the information absent such contractual assurances. ${ }^{50}$ But potential licensees worry that the confidential information will prove either not to be useful, or worse, to be information that they were already aware of, that they were developing independently, or that was publicly available from other public sources. ${ }^{51}$ In such cases, it may be difficult for the licensee to prove that he obtained the information elsewhere, not via misappropriation of the disclosure. ${ }^{52}$ Thus, the potential licensee will be reluctant to enter into contractual assurances of confidentiality without knowing what will be disclosed, and the paradox continues.

Kitch notes that this problem is essentially solved, at least for some types of innovations, by implementation of the patent system. ${ }^{53}$ Patents require, as a quid pro quo for a period of exclusivity, detailed public disclosure of how to make and use the invention claimed in the patent. ${ }^{54} \mathrm{By}$ publicly disclosing technical information, while protecting it by exclusivity, patents circumvent the Arrow paradox..$^{55}$ Patent licensing is no longer a bargain for disclosure, as that has already been accomplished by the publication of the patent. Licensees need only look at the patent to determine whether the information will be valuable to them. Neither need the patentee worry about unauthorized use of the disclosed invention, as it has been secured by a property right that covers the invention regardless of contractual protection. This insight unites the disclosure and property rationales for intellectual property as the solutions to impediments on each side of a transaction between firms.

Kitch's broader theory on patent rights also implicitly-though perhaps unintentionally-illuminates the function of intellectual property in lowering transaction costs within the firm. Kitch argues that the patent system specifically operates not so much as a spur to future invention, but rather as a claim allocation system to encourage efficient commercialization and use of unrealized inventions. ${ }^{56}$ This he analogizes to a "prospect" system of mineral claims, which encourages owners of private

\footnotetext{
50. See Kitch, Nature and Function, supra note 46, at 278.

51. See 4 Roger M. Milgrim, Milgrim ON TRAde SECRETS $§ 15.01[1][d][v]$ (2006).

52. Id.

53. Kitch, Nature and Function, supra note 46, at 266, 277-78.

54. 35 U.S.C. $\$ 112(2000)$.

55. See Arrow, supra note 49, at 619-22.

56. See Kitch, Nature and Function, supra note 46 , at $277-78$.
} 
land to make efficient use of it. ${ }^{57}$ Exclusive rights must be assigned in order to make efficient use of an invention, just as in real property exclusive rights must be assigned in order to make efficient use of mineral resources. Absent such an assignment, investment in the development of an invention will be appropriated by those who have not paid the cost of that investment. The private incentive to develop and market the invention would therefore be less than the social value of the investment. Property rights in each case work to align public and private interests. ${ }^{58}$

Such coordination, Kitch suggests, deters wasteful races or duplicative development of intangible creations. ${ }^{59}$ This approach focuses not so much on assigning ownership in order to create ex ante incentives for creation as on assigning ownership in order to force efficient use of creative works through coordinated licensing. ${ }^{60}$ Indeed, Kitch's approach is somewhat problematic as a theory of incentive. Its basis lies in the classic "tragedy of the commons" ${ }^{11}$ and in the hypothetical world lacking transactions costs that Coase postulated in The Problem of Social Cost. ${ }^{62}$ The tragedy of the commons predicts that exhaustible resources will be overused if publicly accessible, as each individual who uses the resource reaps the benefits of personal use but absorbs only a fraction of the overall costs. $^{63}$ Private property rights are considered the standard antidote for the tragedy of the commons. ${ }^{64}$ Under a private property regime, owners of a resource bear the cost of using a resource, thus aligning private with public interests. ${ }^{65}$ And, to the extent that transactions are costless, owners can engage in arbitrage until each resource is held by the party according it the highest value. ${ }^{66}$

But it is less clear that such a tragedy occurs when the resource is not exhaustible, as in the case of intellectual property. Kitch sidesteps this problem by noting that the resources used to develop intangible goods are often tangible and exhaustible ${ }^{67}$-yet these goods are of course already subject to allocation via the law of chattels and real property. Indeed, even when considered as a theory of efficient intangible resource

57. Id. at $271,273-75$ (making the analogy to land explicit). Analogies between real property and information goods may in many cases be misleading. See Dan L. Burk, Muddy Rules for Cyberspace, 21 CARDOZo L. REV. 121, 134-35, 146-48 (1999) [hereinafter Burk, Muddy Rules]; Dan L. Burk, The Trouble With Trespass, 4 J. SMALL \& EMERGING BuS. L. 27, 53-54 (2000) [hereinafter Burk, Trouble with Trespass].

58. Kitch, Nature and Function, supra note 46, at 276.

59. Id. at 278 .

60. See id. at $275-80$.

61. See Garrett Hardin, The Tragedy of the Commons, 162 SCI. 1243 (1968).

62. Ronald H. Coase, The Problem of Social Cost, 3 J.L. \& ECON. 1, 15-19 (1960).

63. Hardin, supra note 61 , at 1244.

64. Id. at 1247 .

65. See id.

66. See Guido Calabresi \& A. Douglas Melamed, Property Rules, Liability Rules, and Inalienability: One View of the Cathedral, 85 HARV. L. REV. 1089, 1094-95 (1972) (discussing this implication of Coase).

67. Kitch, Nature and Function, supra note 46, at 275-76. 
management, Kitch's approach has been subject to a good deal of wellfounded skepticism. Kitch's emphasis on making a sole and despotic rights holder responsible for coordinating the development, implementation, and improvement of an invention is problematic for precisely the reason that Coase noted in The Problem of Social Cost: specifically, transaction costs not only exist but are likely to be a significant impediment to the transfer of property rights. ${ }^{68}$ The problem of locating and engaging in costly marketplace negotiation with potential licensees will tend to prevent optimal development licensing from occurring. ${ }^{69}$ Additionally, where the marketplace is concerned, we typically believe that competition, rather than monopoly control, will tend to force efficient development of resources. ${ }^{70}$

Yet it is precisely these same objections that lead to the theory of the firm; it is because market transactions are costly that firms organize as hierarchical production centers. The problem of transaction costs and coordination might similarly make the "prospect" theory attractive as an explanation of intellectual property within a firm. Kitch's theory has typically been assumed to apply to coordination of development via licensing between firms. However, this role of coordination for intellectual property resembles property-based theories of the firm, which suggests application of the theory to coordination of development within the firm. The core of Kitch's insight rests on a differential between the relative cost of bargaining in the market and the cost of entrepreneurial control. This is effectively the theory of the firm in the guise of a theory of property rights. Although Kitch does not explicitly contemplate entrepreneurial coordination of such rights within the firm, it is in that setting where such coordination is vital. The idea that intellectual property might serve as a remedy for transaction costs is the first step toward a theory of intellectual property and the firm.

More recent scholarship has begun to explicitly treat the question of intellectual property as a mechanism to lower transactions costs between firms. In one recent study, Oren Bar-Gill and Gideon Parchomovsky have argued that strong intellectual property rights, of the sort the patent system confers, are important to defining the boundary between the firm and the market. ${ }^{71}$ Beginning, as Kitch did, with the problem of Arrow's information disclosure paradox, they examine the implications of patenting not only for disclosure, but also for integration or dis-integration of specialized production functions that would produce innovative information. $^{72}$ They develop a simple model suggesting that strong intellectual

68. Coase, supra note 62 , at $15-16$.

69. See Mark A. Lemley, The Economics of Improvement in Intellectual Property Law, 75 TEX L. REV. 989, 998, 1052-53 (1997).

70. Mark A. Lemley, Ex Ante Versus Ex Post Justifications for Intellectual Property, 71 U. CHI.

L. REV. 129, 135-38 (2004).

71. Bar-Gill \& Parchomovsky, supra note 1, at 1-2.

72. Id. at $3-4$. 
property protection may determine whether specialty functions are brought within a firm. ${ }^{73}$ This is largely because integration offers the only solution to the disclosure problem in the absence of intellectual property protection. Conversely, intellectual property protection offers a solution to the hold-up problem, other than integration. From this outcome Bar-Gill and Parchomovsky derive several corollaries; for example, because innovative information would be subject to appropriation if disclosed in transactions prior to patenting, they argue that innovative prepatent research will most likely be performed within a single firm, rather than contracted out between firms. ${ }^{74}$ They suggest this finding has important implications for the financing and structure of research and development projects. ${ }^{75}$

In a similar vein, Robert Merges has suggested that strong intellectual property rights, such as patents, will play a critical role in facilitating efficient transactions between smaller, dis-integrated, modular firms in what has been dubbed the "post-Chandlerian" economy. ${ }^{76}$ Merges argues that, in the "new economy," innovation will be situated in smaller, nimbler, specialized firms, rather than in large vertically integrated firms. ${ }^{77}$ This industry structure implies a larger number of interfirm transactions, as production functions that once would have been accomplished in-house are contracted out. ${ }^{78}$ This, he suggests, means that property rights will take on an added importance in order to facilitate this increased number of interfirm transactions. ${ }^{79}$ Specialized firms, he predicts, will be fostered by the presence of strong patents because, without patents, high transaction costs would otherwise cause specialized firms to be integrated into larger business conglomerates. ${ }^{80}$

Merges argues that strong property rights facilitate transactions in two ways: first, by overcoming the Arrow information disclosure problem in pre-contractual negotiations,${ }^{81}$ and second, by providing alternative enforcement possibilities after a contract is executed. ${ }^{82} \mathrm{He}$ reviews a number of judicial opinions as case studies for both pre-contractual liability and for post-contractual remedies. ${ }^{83}$ He argues that while courts sometimes find legal theories that impose pre-contractual liability for misappropriation of unpatented information, such claims are uncertain

73. Id. at $3-5$.

74. Id. at 4 .

75. Id. at 5 .

76. See Merges, Transactional View, supra note 2, at 1514; see also Merges, Intangible Assets, supra note 2 , at 1 .

77. Merges, Transactional View, supra note 2, at 1513-14.

78. Id. at 1514 .

79. Id. at 1516 .

80. Id. at 1519 .

81. Id. at 1503 .

82. See id. at 1504

83. See id. at 1491-1513. 
and proof of misappropriation in such cases is difficult. ${ }^{84}$ Consequently, he suggests that the presence of a property right "against the world" will foster licensing relationships between firms. ${ }^{85}$ Importantly, he notes the existence of other appropriability mechanisms, such as trusted relationships, but emphasizes that property rights are "tried and true" legal mechanisms for deterring opportunism. ${ }^{86} \mathrm{He}$ also notes that the presence of patents may facilitate disclosure of information related to the patentin other words, that patents themselves function as appropriability mechanisms for integrally related trade secrets and know-how. ${ }^{87}$

With regard to post-contractual remedies, Merges notes that the presence of a property right offers property owners a second set of legal claims in addition to, or in lieu of, breach of contract claims. ${ }^{88}$ In the United States, the choice between a claim for breach of contract and a claim for patent infringement may mean a choice of forum between federal court or state courts. ${ }^{89}$ Since each court system entails its own expertise, this choice may be important to a rights holder. The choice between patent and contract claims may also affect the calculation of statutes of limitations ${ }^{90}$ and the measure of damages available. ${ }^{91}$ Although Merges' particular examples are idiosyncratic to the U.S. system, presumably his overall point is likely applicable as a general matter: property rights will offer different remedy options than contracts, and knowing those additional remedies are available ex post may prompt more bargains ex ante.

In earlier, unpublished work from the late 1990s, Merges pursues an even more ambitious agenda of applying the theory of the firm to interfirm intellectual property transactions. ${ }^{92}$ There he employs the GHM residual property model to argue that the availability of strong property rights in the form of patents not only facilitates transactions with specialty firms, but actually prompts the formation of such specialty firms. ${ }^{93}$ In the GHM model, property rights allow a specialty firm to redeploy a specialized asset should the contracting firm default on the agreement, and Merges extends this argument to intellectual property rights. Perhaps most critically, Merges notes that, unlike the standard GHM model where the asset developed is tangible, and so has the characteristic of physical rivalrousness, intellectual property assets are nonrivalrous. ${ }^{94}$ In the case of physical property, possession implies exclusion, and the ability to redeploy the asset. But physical exclusion is frequently impossible

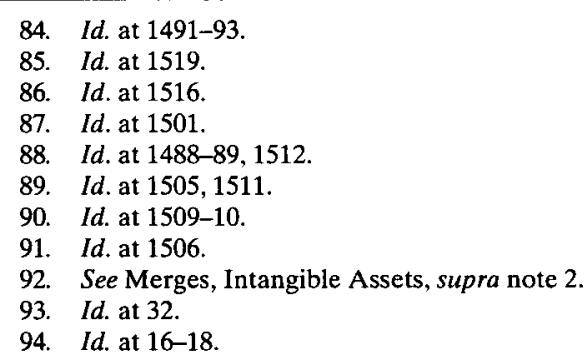


for the intangible asset, so that absent legal exclusion, deployment risks loss of control. And such loss of control precludes the independent existence of a specialty firm, leaving instead the option of integrating into a larger firm where loss of control would not be an issue. ${ }^{95}$

Merges also reviews anecdotal case studies that illustrate his arguments, together with a survey of empirical studies that appear to support more licensing by specialty firms as patents become available. ${ }^{96}$ The overall claims in this work are properly hedged by a number of important and sophisticated caveats. Merges recognizes certain limitations of the GHM model, but focuses on the general proposition that residual control of property is important to the firm. ${ }^{97}$ He also recognizes that property rights are not always a panacea, admitting that over-propertization can sometimes decrease efficiency and musing whether this may not be the case if residual rights are improperly allocated in the firm. ${ }^{98}$ In particular, he notes that efficiency may be decreased where an "anticommons" of fragmented over-propertization occurs. ${ }^{99}$

In related work with Ashish Arora, Merges has continued this line of argument, articulating a model where, under certain conditions, the availability of strong intellectual property rights will favor independent suppliers over integrated production. ${ }^{100}$ Arora and Merges develop a stylized model of supply firm dis-integration, incorporating assumptions from the literatures on appropriability, transaction cost economics, and residual property rights. ${ }^{101}$ They particularly examine supply firm integration or independence under conditions of information "spillover" or "leakage" in interfirm transactions, assuming that incentives for innovation are greater for independent supply firms. ${ }^{102}$ Their model predicts that where a supply relationship is likely to produce information valuable to the supplier, the availability of strong intellectual property rights will favor independent suppliers over integrated production. ${ }^{103}$ Significantly, the model also predicts that where information leakage is present, the effect of property rights such as patents is ambiguous, and integration within the firm will be often preferable. ${ }^{104}$ But they suggest that the benefits to innovation of fostering specialized firms must temper the concerns over the proliferation of patents, and particularly concerns over the creation of a fragmented patent "anticommons." 105

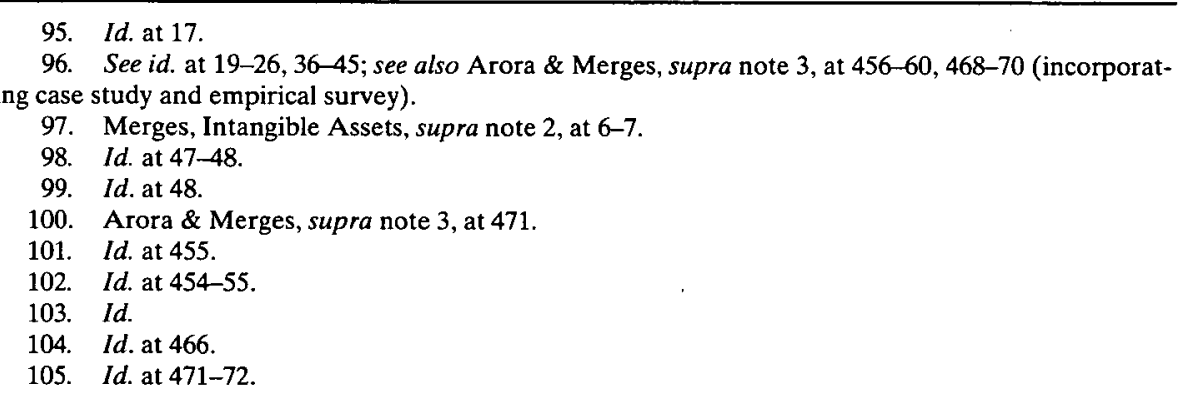




\section{Intellectual Property Within the Firm}

The literature reviewed above forms the foundation for a newly emerging body of scholarship on the role of intellectual property in lowering the firm's transaction costs. But nearly all of this work has been targeted toward the interaction between firms, and the decision whether to "make or buy" a particular specialized input; that is, ultimately, whether to outsource production or whether to integrate production within a given firm. But the theory of the firm examines not only the boundary of the firm looking from the outside in, but also the boundary of the firm looking from the inside out. Coase and those analysts following him offer predictions as to the internal organization of the firm.

Indeed, while securing firm assets against internal hold-up or misappropriation is an important consideration for any type of asset, it may be particularly important and particularly tricky for intellectual property. The employee welding fenders onto cars on the assembly plant floor probably feels little sense of ownership toward the automobiles she is helping to manufacture, and the right to possession of the physical product is relatively clear as between the employee and the firm. But an employee who makes fundamental new discoveries in chemistry, or who develops a customer list based on personal contacts, may feel a strong personal entitlement to such intangible.properties and may have difficulty separating personal entitlement from that of the firm. In some cases, the sense of entitlement may be mixed, as perhaps in the case of a technical writer who feels some pride of authorship in a manual prepared for the firm, but no sense of ownership in the text produced. ${ }^{106}$

Relatively little has been said to date regarding the role of intellectual property rights in shaping such intra-organizational characteristics of the firm. Bar-Gill and Parchomovsky briefly suggest in their paper that intellectual property law will affect the mobility and incentives of employees within the firm. ${ }^{107}$ Robert Merges has argued that strategic bargaining analysis, team production theory, principal-agent theory, and common sense all argue in favor of default rules that favor firm ownership over employee ownership. ${ }^{108}$ And one of us (Burk) has previously probed the effects that intellectual property may have within the firm, helping to secure the firm's intangible assets from misappropriation or waste, coordinating the use of the firm's intangible assets, and protecting the firm from employee hold-up when assets have been committed to specific projects. ${ }^{109}$

Just as in the case of interfirm transactions, such analysis begins by analyzing the misappropriation regime of trade secrets, then contrasts

106. In such cases, Burk has suggested that authorship and ownership might be allocated differently than under current copyright work made-for-hire doctrines. See Burk, supra note 4, at 14-15.

107. See Bar-Gill \& Parchomovsky, supra note 1, at 5-6.

108. See Merges, supra note 7, at 2-3.

109. See Burk, supra note 4. 
trade secrets with the property-based systems of copyright and patent. Common flashpoints for trade secrecy disputes are not only the exchange of information between firms partnering in some venture, but also employee departures from the firm. ${ }^{110}$ When employees move between firms, typically between firms in the same industry, valuable firm information may move with them. Courts policing trade secret disputes are placed in the difficult position of attempting to sort out firm-specific assets from the employee's general human capital; sound policy dictates that the former sort of information remain with the firm, but the latter should move freely in the labor market. ${ }^{111}$ Overprotecting the firm's assets risks barring the individual from areas of employment where she is most skilled and best able to earn a livelihood. ${ }^{112}$ Underprotection of the firm's assets risks allowing competitors to hire employees away specifically to misappropriate valuable information.

This creates a type of disclosure paradox paralleling that in negotiations between firms. Employees may have difficulty moving between firms because trade secrecy or related confidentiality mechanisms prevent them from showing the prospective employer the most creative work performed for the former employer. Prospective employers may also be reluctant to hire employees who might inadvertently place the new employer at risk of actual or apparent trade secret misappropriation. ${ }^{113}$ Patent and copyright facilitate the employee's ability to display creativity and skills to prospective employers in a manner similar to their enhancement of interfirm production negotiations. The disclosure protections inherent in patent, or for that matter in copyright, will allow an employee to display such properties as part of a résumé or portfolio, without risk that the prospective employer, who may well be a competitor of the employee's previous employer, will misappropriate them. The property right also helps put prospective employers on notice as to what assets are considered proprietary to the previous employer.

In previous work, one of us (Burk) has also noted that an important feature of trade secrecy has been the requirement that firms indicate or mark information considered proprietary, helping to put employees on notice as to what is considered a firm-specific asset and assisting courts in sorting the firm's information from the employee's personal abilities. ${ }^{14}$ But because trade secrets are difficult to specify, sorting the proprietary from the nonproprietary is costly and difficult. The impossibility of the task may well make the social cost of determining what should be pro-

110. 1 MILGRIM, supra note $51, \$ 5.02$.

111. See Kitch, Valuable Information, supra note 46 , at 684-85.

112. See Katherine V. W. Stone, Knowledge at Work: Disputes Over the Ownership of Human Capital in the Changing Workplace, 34 CONN. L. REV. 721, 742 (2002).

113. See, e.g., Pepsico Inc. v. Redmond, 54 F.3d 1262, 1271 (7th Cir. 1995) (holding that an employee hired from a competitor will "inevitably disclose" proprietary information from the previous employer); see also Stone, supra note 112, at 758 (summarizing inevitable disclosure doctrine).

114. See Burk, supra note 4 , at 10. 
tected higher than the social value of the determination, leading to all or nothing rules of no enforcement at all or complete enforcement.

As in the case of interfirm transactions, exclusive forms of intellectual property can help. First, the nature of the patent itself will tend to place employees on notice as to the borders of a firm's intellectual assets, via the same mechanisms that we expect to facilitate interfirm transactions. Notice to the public of a patent's metes and bounds is a blackletter provision of patent law ${ }^{115}$ but that same notice will serve to alert employees to the scope of patent assets assigned to the firm. Thus, the disclosure provisions of the patent statute require that the patent application, which will eventually be published when the patent issues, entail a written description of the invention sufficiently detailed to allow one of ordinary skill to make and use the invention. ${ }^{116}$ Similarly, the statute requires that the patent include sufficiently definite claims to allow one of ordinary skill in the art to know what is covered by the patent. ${ }^{117}$ To be sure, language is an imprecise tool, and like any other document, patents require interpretation. ${ }^{118}$ Not every ambiguity concerning a patented asset will be resolved by the patent disclosure requirements, but it is difficult to imagine how better to implement a mechanism for demarcating an intangible asset.

Second, the process of obtaining a patent will tend to demarcate firm assets from employee assets. Securing a patent requires substantial sophistication; indeed, some commentators have suggested that the presence of patents as firm assets constitutes a signal to investors of management sophistication. ${ }^{119}$ As a corollary, the financial investment necessary to draft and prosecute a patent application is not inconsiderable. Although the financial investment to secure a patent will generally seem comparatively modest in the context of the financing mechanisms of a firm, the price of a patent will usually seem more substantial against an inventor's personal resources. The investment of firm resources in obtaining a patent will tend to put employees on notice as to the firm's interest in the patented invention; conversely, employees will typically not casually or accidentally obtain patent rights in inventions that the firm considers a firm asset. In cases where the employee does obtain a patent for work done within the firm, courts will often find that an express or implied duty gives rise to a "shop right" that allows the employer nonexclusive use of the invention. ${ }^{120}$

\footnotetext{
115. 35 U.S.C. $\$ 112(2000)$.

116. Id. II 1.

117. Id. II 2.

118. On the ambiguities of claim interpretation, see Dan L. Burk \& Mark A. Lemley, Quantum Patent Mechanics, 9 LEWIS \& ClaRK L. ReV. 29, 32-40 (2005).

119. See Clarisa Long, Patent Signals, 69 U. CHI. L. Rev. 625, 646 n.56, 653 (2002). But see Meurer, supra note 41 , at 747 (disputing the plausibility of patents as a management signal).

120. See Burk, supra note 4, at 16; Merges, supra note 7 , at 16.
} 
In contrast to the formal process of patenting an invention, copyright arises spontaneously, upon fixation of a creative work in a tangible medium of expression, without the necessity of external review or examination. ${ }^{21}$ It is unlikely that the firm would wish to assert or retain rights to every memo, email, or other copyrightable work generated by employees if a vigorous external review were required; the effort of registering and policing all these works would be prohibitive. Although copyright arises automatically, U.S. law currently requires registration with the Copyright Office before the copyright can be enforced; ${ }^{122}$ thus the mechanics of registration can for the most part be ignored unless and until a justiciable dispute arises. And, where such material is generated by an employee within the scope of employment, U.S. copyright law automatically assigns authorship as "work made for hire" to the employer. ${ }^{123}$ Compared to patentable inventions, the investment in creating such works is typically relatively small, and the default rule for firm ownership is concomitantly stronger than that of the "shop right."

Such rules governing the creation and assignment of patents, copyrights, and trade secrets all entail or have evolved to provide significant employer control of firm-specific intellectual assets, as well as helping to determine which intellectual assets are firm-specific and which are employee-specific. Significantly, doctrines such as the "shop right" and "work made for hire" have developed in reliance on the law of agency and fiduciary duty. Thus, intellectual property law tends to assign rights to firms where the ideas are developed within the scope of employment using firm resources. ${ }^{124}$

Paul Heald has argued in a similar vein that transaction-cost economics can explain many features of patent law, as adjuncts to or replacements for corporate forms of firm governance. ${ }^{125}$ Heald focuses on arguments regarding "asset partitioning" and "team production" costs. ${ }^{126}$ Some commentators on corporate law have suggested that the corporation prevents heirs or creditors from claiming assets previously pledged to firm-specific projects. ${ }^{127}$ Heald notes that patent assignments may play a similar role, particularly given the recordation feature of the patent system. ${ }^{128}$ Similarly, recordation of patents may ameliorate costs associated with team production, that is, the distribution of rewards when work is done in a team setting. Corporate law commentators have suggested that the corporate form provides a neutral overseer to distribute rewards, or

121. 17 U.S.C. $\S 102(2000)$.

122. Id. $\$ 411$.

123. Id. $\$ 201(\mathrm{~b})$.

124. See Burk, supra note 4 , at $17-18$.

125. See Heald, supra note 6 .

126. See id.

127. See Henry Hansmann \& Reinier Kraakman, The Essential Role of Organizational Law, 110 YALE L.J. 387, 394 (2000).

128. See Heald, supra note 6 , at 482 . 
to deter shirking in cooperative work. ${ }^{129}$ Heald has argued that patenting reduces costs of monitoring and tracking employee work augmenting the benefits of corporate organization. ${ }^{130}$

These applications of intellectual property are largely consonant with the various forms of business association law that address similar issues. ${ }^{131}$ People working for a principal, a partnership, a corporation, or so on, often face the question of whether they can pursue a business opportunity on their own or must instead offer it to the business for which they work. This was the situation at issue in perhaps the most famous fiduciary duty case of all, Meinhard $v$. Salmon. ${ }^{132}$ Two joint venturers leased and managed a hotel in New York, with one providing money and the other doing the work. ${ }^{133}$ When the time came for renewal, the latter wound up striking a deal with the property owner without involving his partner in the new deal. ${ }^{134}$ The question was whether this was an opportunity that belonged to the partnership, and hence should have been presented to it. ${ }^{135}$

Judge Cardozo answered yes, in classic language: "A trustee is held to something stricter than the morals of the market place. Not honesty alone, but the punctilio of an honor the most sensitive, is then the standard of behavior." tunity concerned the very property that was at the heart of the partnership. ${ }^{137}$ "If Salmon had received from Gerry a proposition to lease a building at a location far removed, he might have held for himself the privilege thus acquired, or so we shall assume. Here the subject-matter of the new lease was an extension and enlargement of the subject-matter of the old one." 138

Corporate law draws a similar line. The leading case on the corporate opportunity doctrine is Guth v. Loft. ${ }^{139}$ The Guth rule states:

[I]f there is presented to a corporate officer or director a business opportunity which the corporation is financially able to undertake, is, from its nature, in the line of the corporation's business and is of

129. See, e.g., Margaret M. Blair \& Lynn A. Stout, A Team Production Theory of Corporate Law, 85 VA. L. REV. 247,250 (1999).

130. See Heald, supra note 6 , at 492 . Heald may be overly optimistic about the efficacy of patenting in monitoring employee output. See Burk, supra note 4, at 18-19 (noting the difficulty of determining patent inventorship in large $R \& D$ operations). In drawing upon team production theory, Heald also runs the risk of inheriting the difficulty in explaining why mediating hierarchs have adequate incentive to manage the affairs of the business in an energetic, competent, and honest way.

131. See, e.g., D. Gordon Smith, The Critical Resource Theory of Fiduciary Duty, 55 VAND. L. REV. 1399, 1444-47 (2002). Smith's application of the theory of the firm to fiduciary duties has clear implications for trade secrecy. See Burk, supra note 4, at 4.

132. 164 N.E. 545 (N.Y. 1928).

133. Id. at 546 .

134. Id.

135. Id.

136. Id.

137. Id. at 548 .

138. Id.

139. 5 A.2d 503 (Del. 1939). 
practical advantage to it, is one in which the corporation has an interest or a reasonable expectancy, and, by embracing the opportunity, the self-interest of the officer or director will be brought into conflict with that of his corporation, the law will not permit him to seize the opportunity for himself. ${ }^{140}$

The Guth corollary states:

It is true that when a business opportunity comes to a corporate officer or director in his individual capacity rather than in his official capacity, and the opportunity is one which, because of the nature of the enterprise, is not essential to his corporation, and is one in which it has no interest or expectancy, the officer or director is entitled to treat the opportunity as his own, and the corporation has no interest in it, if, of course, the officer or director has not wrongfully embarked the corporation's resources therein. ${ }^{141}$

Thus, two crucial factors are whether the employee learned about the opportunity while at work, and whether she used corporate resources in developing the opportunity. ${ }^{142}$ The line strongly resembles that of the work for hire doctrine, and again shows courts moving toward the demarcation line of asset specificity. ${ }^{143}$

Business law has also dealt with the question of how agents may use confidential information that they have gained while working for a principal. The basic rule is that they cannot use such information without the principal's consent. The rule is strictest while the agent remains an agent:

Unless otherwise agreed, an agent is subject to a duty to the principal not to use or to communicate information confidentially given him by the principal or acquired by him during the course of or on account of his agency or in violation of his duties as agent, in competition with or to the injury of the principal, on his own account or on behalf of another, although such information does not relate to the transaction in which he is then employed, unless the information is a matter of general knowledge. ${ }^{144}$

Note that this covers confidential information acquired "during the course of or on account of his agency"145 - again, pointing to resources acquired within the scope of employment.

140. Id. at 511 .

141. Id. at $510-11$.

142. For further analysis of the corporate opportunity doctrine, see Eric Talley, Turning Servile Opportunities to Gold: A Strategic Analysis of the Corporate Opportunities Doctrine, 108 Y ALE L.J. 277 (1998), and Victor Brudney \& Robert Charles Clark, A New Look at Corporate Opportunities, 94 HARV. L. REV. 998 (1981). Talley's analysis in particular is quite pertinent for our discussion in this article.

143. See Burk, supra note 4 , at 18.

144. RESTATEMENT (SECOND) OF AGENCY $\$ 395$ (1958).

145. Id. 
There is somewhat less restriction on using confidential information after the agent has ceased being an agent, but there are still some significant limits.

Unless otherwise agreed, after the termination of the agency, the agent ... has a duty to the principal not to use or to disclose to third persons, on his own account or on account of others, in competition with the principal or to his injury, trade secrets, written lists of names, or other similar confidential matters given to him only for the principal's use or acquired by the agent in violation of duty. The agent is entitled to use general information concerning the method of business of the principal and the names of the customers retained in his memory, if not acquired in violation of his duty as agent .... ${ }^{146}$

Here again, information that is specific to the principal is protected, while general information is not.

Thus, agency and corporate law generally resemble intellectual property law in how they divide rights to information generated within a firm. That line is close to what one would expect from the theory of the firm: information whose usefulness is specific to the firm belongs to the firm, while employees can use for themselves more general information. ${ }^{147}$ We would like to believe that these different areas of the law have developed the same distinctions because they track the most efficient rule, although it is also possible that courts and legislators creating intellectual property law simply drew upon the well-known and wellestablished principles of agency law, so that the intellectual property rules are not separate confirmation of the good qualities of the rules.

A different pattern emerges as we move from the rules initially assigning property rights between firms and their members to the rules that govern how those rights can be reassigned. Here, the rules of intellectual property law function rather differently from those of business association law. The differences make sense given the different purposes of the two sets of laws. In brief, intellectual property law makes transfer of rights relatively easy to accomplish, whereas business association law creates higher hurdles for certain transfers, particularly transfers of rights to the directors, officers, or controlling shareholders of corporations. These hurdles exist to control conflicts of interest, which are a central concern of business association law.

Complying with the rules for transferring rights under the intellectual property laws is relatively straightforward; in general, intellectual property is alienable and devisable by contract or other operation of law, as any other property. In a few instances, the statute places explicit restrictions on transfers - for example, copyright requires a signed writing in order to transfer exclusive rights, so that transfer by implied license or

146. Id. \$ 396(b).

147. See Smith, supra note 131 , at 1419. 
contracts implied in fact are limited to nonexclusive rights. ${ }^{148}$ The patent statute includes a recordation provision that secures the priority of registered patent assignments. ${ }^{149}$ The copyright statue contains a similar recordation provision. ${ }^{150}$ In some cases, the policies animating such formalities are clear; for example, Congress has created an unwaiveable reversionary interest in the transfer of exclusive rights in order to protect unwary authors-somewhat paternalistically-against overreaching licenses. ${ }^{151}$

Agency and corporate law may for their own purposes create greater obstacles to transfers of intellectual property rights, depending upon circumstances and to whom the rights are being transferred. Whenever rights are being transferred from a principal to an agent, or from a corporation to a director, officer, or employee, fiduciary duty rules apply, and they may create significant limits on the transfer. ${ }^{152}$ Fiduciary duty rules apply to the use of corporate opportunities or the use of confidential information. ${ }^{153}$ They also apply to the licensing of intellectual property rights just discussed, where a principal is on one side and her agent on the other. ${ }^{154}$

Such transactions require approval by the principal, in the case of agency law, ${ }^{155}$ or of the corporation, in the case of corporate law. ${ }^{156}$ The procedural stringency imposed on such consent depends on circumstances. Under basic agency law, the main requirement is that the principal must be fully informed of all relevant material information that the agent possesses concerning the transaction. ${ }^{157}$

An agent who, to the knowledge of the principal, acts on his own account in a transaction in which he is employed has a duty to deal fairly with the principal and to disclose to him all facts which the agent knows or should know would reasonably affect the principal's judgment, unless the principal has manifested that he knows such facts or that he does not care to know them. ${ }^{158}$

This strong information requirement goes beyond the standard contractual principle of good faith that governs licensing under the intellectual property laws. The fairness requirement in the quoted language also goes beyond ordinary good faith.

\footnotetext{
148. 17 U.S.C. $\$ 204(a)(2000)$.

149. 35 U.S.C. $\$ 261$ (2000).

150. See 17 U.S.C. $\$ 205(\mathrm{c})$; Quality Records, Inc. v. Coast to Coast Music Inc., Copyright L. Rep. (CCH) II 27,659 (9th Cir. 1997).

151. See 17 U.S.C. $\$ \$ 203,304$ (c); see also Stewart v. Abend, 495 U.S. 207, 220-21 (1990).

152. See, e.g., RESTATEMENT (SECOND) OF AGENCY $\$ \$ 389,395,396$ (1958); FRANKLIN A. GeVurtz, CoRPoration LAW $\S \S 4.2 .4-2.9$ (2000).

153. See RESTATEMENT (SECOND) OF AGENCY $\$ \$ 395,396$ (use of confidential information).

154. See id. $\$ 389$ (acting as an adverse party).

155. See id. $\$ \S 390,395 \mathrm{cmt}$. c.

156. See GeVURTZ, supra note $152, \S 4.2 .9$ (b), at 386 .

157. See RESTATEMENT (SECOND) OF AGENCY $\S 390 \mathrm{cmt}$. a.

158. Id. $\$ 390$.
} 
For transactions within a corporation, the procedural requirements can be stronger, depending on the party with whom the corporation is transacting. Requirements are simplest for transactions with simple employees. For these, approval by a superior with the required authority following full disclosure should generally suffice. ${ }^{159}$

Transactions with directors, top officers, or controlling shareholders face greater obstacles. For these, there is something of a puzzle as to whose approval should count as blessing the transaction. The board of directors formally controls a corporation; therefore, if a transaction involves a party with ties to one or more of the directors, can we trust the board to act in the best interests of the corporation? Corporate law has developed a three-pronged approach: self-dealing transactions are valid if one of three tests is met. The transaction must be approved, following full disclosure, by a majority of the independent and disinterested directors, or by a majority of the disinterested shareholders, or must be shown to be fair to the corporation. ${ }^{160}$ The same basic rule probably applies to officers as well. ${ }^{161}$

Corporate law also creates special procedures for transactions with shareholders who control the board, but do not own all of the corporation's shares. ${ }^{162}$ The concern here is that the controlling shareholder could get the board to approve a transaction that benefits the shareholder at the expense of minority shareholders. In Delaware, as in many states, such a transaction must be shown to be fair to the corporation. ${ }^{163}$ Approval by independent directors or shareholders simply shifts the burden of proof on fairness. ${ }^{164}$

Thus, agency and corporate law apply procedural limits on transfers of property rights from a firm to its agents that go beyond the transfer rules of intellectual property law. Why is this so? Such transfers create potential conflicts of interest between firms and their members. One of the key functions of agency and corporation law is to address such conflicts. The law attempts to do so in a way that protects firms from possible exploitation by their agents while still providing plenty of flexibility for private ordering. Intellectual property law rules apply not just to such intrafirm transactions, but also to interfirm transactions where such conflicts are generally not present and bargaining occurs at arms-length. For those transactions, fiduciary duty rules are unnecessary. Thus, we need not have the same legal protections for such transactions. The intellectual property rules, which apply to both, thus set a minimal level of procedure required to effect a valid transfer, and we use agency and cor-

\footnotetext{
159. See GEVURTZ, supra note $152, \S 4.2$.

160. See Del. Code ANN. $\$ 144$ (2006); Model Bus. CoRP. ACt $\S \S 8.60-.63$ (2003).

161. See GEVURTZ, supra note $152, \$ 4.2 .1$, at 324 .

162. See id. $\$ 4.2 .4$, at 346 .

163. See Weinberger v. UOP, Inc., 457 A.2d 701, 703 (Del. 1983).

164. See id.
} 
porate law to provide greater protections in transactions where such protection is useful.

\section{CONSIDERING VARIETIES OF INTELLECTUAL PROPERTY}

Our discussion to this point has summarized and extended the analysis of intellectual property and the firm. The previous analyses we have discussed tended to focus on the contrast between the transaction cost profiles of trade secrets and patents; relatively little has been said about other forms of intellectual property, such as copyright. ${ }^{165}$ But in exploring the role of intellectual property vis-à-vis the firm, it quickly becomes clear that firms hold intellectual property in multiple forms, not only patents, but also copyrights, trade secrets, trademarks, and other varieties. Why might firms hold multiple forms of intellectual property, and what effect do they have on the internal and external transaction costs of the firm? In this Part we consider several examples of the role that different types of intellectual property may play. in transactions between firms, as well as transactions within firms. As previous commentators have done, we begin with the characteristics of trade secrecy.

\section{A. Considering "Strong" Intellectual Property}

Arrow's information disclosure paradox suggests that firms will have difficulty licensing information due to the possibility of misappropriation; ${ }^{166}$ employee access to valuable information generates similar dangers to the firm. An obvious first attempt to solve these problems might be for parties to require confidentiality as a matter of contract, or to impose a duty of confidentiality sounding in tort or unjust enrichment. These are the origins of trade secrecy, which provides some degree of remedy to the misappropriation of valuable business information. ${ }^{167}$

But trade secrecy does not confer a true property right in the sense that it confers no right to exclude third parties from the subject matter of the secret. ${ }^{168}$ In particular, independent development and reverse engineering are legitimate methods to acquire the trade secret. ${ }^{169}$ Consequently, the holder of the trade secret has no ability to exclude inde-

165. An exception is the intrafirm analysis in Burk, supra note 4.

166. See Heald, supra note 6 , at 494.

167. See Richard H. Stern, A Reexamination of Preemption of State Trade Secret Law After Kewanee, 42 GEO. WASH. L. REV. 927, 937-38 (1974) (reviewing the common law bases of trade secrecy).

168. See Friedman et al., supra note 47 , at 62 (defining trade secrecy as a liability rule regime). Traditionally, courts explicitly rejected classification of trade secrets as property. See RESTATEMENT OF TORTS \$ $757 \mathrm{cmt}$ a (1939); E.I. DuPont de Nemours Powder Co. v. Masland, 244 U.S. 100, 102 (1917). More recent cases tend toward the view of trade secrets as property. See Pamela Samuelson, Information as Property: Do Ruckelshaus and Carpenter Signal a Changing Direction in Intellectual Property Law?, 38 CATH. U. L. REV. 365, 366 (1989).

169. UNIF. TRADE SECRETS ACT $\$ 1 \mathrm{cmt}$., 14 U.L.A. commentary; RESTATEMENT OF TORTS $\$ 757$ cmt. a (1939). 
pendent developers or reverse engineers from using the information. ${ }^{170}$ Perhaps more important, the holder of the trade secret has no ability to promise a licensee that independent developers or reverse engineers will not begin to use the trade secret. ${ }^{171}$ Rather, when the information is not generally known in the industry and the holder of the information takes reasonable steps against public disclosure, trade secrecy confers protection against certain types of misappropriation. ${ }^{172}$

The practical result of this system is that the licensee of a trade secret is really bargaining for disclosure, rather than for exclusivity. ${ }^{173}$ These features of trade secrecy also place a natural limit on the price that can be charged for access to a trade secret; the price must be something less than the cost to the licensee of reverse engineering or independently developing the information. ${ }^{174}$ Consequently, the price paid for the disclosure of the trade secret will be essentially the value that the licensee receives from the "head start" of disclosure, rather than having to incur the costs of independent development. And as a corollary, not surprisingly, this is the most common measure of damages in cases of trade secret misappropriation: a damages award or an injunction equivalent to the monetary or temporal "head start" that the rogue competitor obtained by misappropriation. ${ }^{175}$

As a consequence of these features, Kitch, Merges, and others point out that the combination of contract, quasi-contract, and tort that comprises trade secret law offers some degree of protection against misappropriation of project-specific assets, but this protection is problematic and often incomplete. ${ }^{176}$ From this they argue the utility, and indeed the necessity, of stronger intellectual property regimes. ${ }^{177}$ Reviewing such analyses, one might conclude that it is nearly impossible for firms to exchange information that is unprotected by a strong property regime.

We note as an initial matter that practical experience proves this supposition to be as wrong as wrong can be. Firms can and do routinely exchange unpatented information. To be sure, there are risks in doing so, and managers of a firm are aware of such risks, although managers often seem somewhat less exercised about the risks than are the firm's lawyers. Indeed, anecdote, experience, and ethnography remind us that such exchanges frequently occur on the basis of no more than a hand-

\footnotetext{
170. See 2 MiLGRIM, supra note $51, \S 7.02[1][$ a] \& n.1.

171. Id. $\$ 7.02[1][\mathrm{c}]$.

172. See generally RESTATEMENT OF TORTS $\$ 757$.

173. See 2 MiLGRIM, supra note 51, § 7.02[1][c].

174. Martin J. Adelman, Property Rights Theory and Patent-Antitrust: The Role of Compulsory Licensing, 52 N.Y.U. L. REV. 977, 981-82 (1977).

175. See UNIF. TRADE SECRETS ACT $\$ \S 2 \mathrm{cmt} ., 3 \mathrm{cmt} ., 14$ U.L.A. 433, 449 (1990).

176. See Kitch, Valuable Information, supra note 46, at 689-708; Merges, Intangible Assets, supra note 2 , at 6-7.

177. See Kitch, Valuable Information, supra note 46, at 709-10; Merges, Intangible Assets, supra note 2 , at 8 .
} 
shake or verbal agreement. ${ }^{178}$. Cases of bargaining breach or breakdown, such as those surveyed by Merges, are likely the exception-of the millions of business transactions that occur each year, it is unclear how many result in disputes, but it seems safe to say that few of those disputes result in litigation. Relatively few disputes are resolved by formal legal mechanisms; very few of the cases filed in court proceed to trial, fewer proceed to appeal, and fewer yet are reported as published opinions. ${ }^{179}$

Thus, conclusions drawn from a survey of the case law must be approached with caution. Only the most pathological situations are reported as judicial opinions; the majority have settled or reached some other resolution. Settlement and other informal dispute resolutions may of course be helped along by the presence of property rights or other clear entitlements; parties are more likely to reach agreement where their estimates of cost and benefit are aligned. But informal resolutions may be primarily facilitated by the norms and relationships of the business community. Firms are most often repeat players. Bargaining in the marketplace is a multi-round game rather than a single shot, and there are likely to be substantial reputational penalties for "defecting" from the game by misappropriating intellectual property. This is particularly true in concentrated industries, where opportunities for partnerships are limited, and today's competitor may be tomorrow's essential resource.

Consequently, we must be modest about the role of property rights or any other formal legal mechanisms in encouraging interfirm transactions; they may operate mostly in the background, and may mostly affect the marginal case. Moreover, nonlegal mechanisms differ over space and across time, and the optimal law may vary depending on the nonlegal mechanisms. Given that caveat, we cannot lightly dismiss the role of contract-based legal protections to interfirm transactions. Backed by the norms and informal expectations of the community, we suggest that the law of contract, unjust enrichment, and trade secrets provide rather significant legal deterrents to misappropriation of nonpatented information. Professor Merges emphasizes that these legal mechanisms sometimes fail and surveys a number of cases illustrating such failures. ${ }^{180}$ But such re-

178. See Walter W. Powell et al., Interorganizational Collaboration and the Locus of Innovation: Networks of Learning in Biotechnology, 41 ADMIN. SCI. Q. 116, 120 (1996).

179. For evidence that most grievances never result in a legal claim, and that most legal claims do not result in a contested judgment, see Kevin M. Clermont \& Theodore Eisenberg, Litigation Realities, 88 CORNELL L. REV. 119, 135-37 (2002). For evidence that only about a fifth of judgments undergo an appeal, see $i d$. at $151-52$. For evidence that nearly $80 \%$ of federal court opinions are unpublished, see Chad M. Oldfather, Remedying Judicial Inactivism: Opinions as Informational Regulations, 58 FLA. L. REV. 743, 772 (2006).

180. In touting patents as a preferable alternative, Merges largely neglects the converse problem, which is nonetheless pertinent: patents and their attendant licenses also sometimes fail. In fact, the patent system to some extent relies upon such failures as opportunities to weed out weak patents, encouraging licensees to challenge and invalidate patents, on the theory that there are few potential challengers who have better information and better incentives to identify bad patents than their licensees. See, e.g., Lear v. Adkins, 395 U.S. 653, 671-74 (1969); see also MedImmune, Inc. v. Genentech, Inc., 
ported cases are the merest tip of the iceberg of business experience, and it bears remembering that these legal mechanisms also often succeed. Simply the threat of litigation, with its attendant costs and inconveniences, may be enough to deter defections where the payoff for strategic behavior is relatively low.

Nonetheless, there are undoubtedly situations where trade secrecy proves inadequate, and doubtless situations where bargains do not occur because firms know that trade secrecy may be inadequate. Thus, the previous analyses by Merges, by Merges and Arora, and by Bar-Gill and Parchomovsky consider, and clearly favor, provision of what they designate as "strong" intellectual property rights. ${ }^{181}$ Patents appear to be their paradigm for such rights, set in opposition to trade secrets or purely contractual restrictions, which, lacking the right to exclude, cannot properly be considered property rights at all. Yet beyond the obvious contemplation of patents, none of these previous discussions articulate what exactly is meant by "strong" property rights, even though such rights are thought to lead to desirable efficiencies in interfirm transactions.

In previous work, Burk has analyzed what may be meant by "strong" property rights in the literature that uses such terms, concluding that this nomenclature typically involves a confluence of at least three aspects of property rights, each of which exists on a continuum of possible legal formulations. ${ }^{182}$ First, discussions of "strong" property tend to contemplate property as designated in the nomenclature famously developed by Calabresi and Melamed. ${ }^{183}$ In this framework, property entails a robust right to exclude, as opposed to a liability regime that would contemplate a right to recover damages. ${ }^{184}$ Patents are indeed the paradigm case for intellectual property in this dimension, as they are couched in terms of exclusive rights ${ }^{185}$ and carry with them. strong injunctive remedies. ${ }^{186}$ Other forms of intellectual property, particularly copyright, may also carry exclusive rights and injunctive remedies, but incorporate aspects of liability regimes, such as compulsory licensing. ${ }^{187}$ Consequently,

127 S. Ct. 764 (2007) (licensee challenge to patent validity presents a case or controversy for declaratory judgment).

181. See Arora \& Merges, supra note 3, at 471-72; Bar-Gill \& Parchomovsky, supra note 1, at 2; Merges, Intangible Assets, supra note 2, at 32.

182. See Burk, Muddy Rules, supra note 57, at 129-30.

183. See Calabresi \& Melamed, supra note 66.

184. Id. at 1107 .

185. See 35 U.S.C. \& 271(a) (2000).

186. See 35 U.S.C. $\$ 283$. The Federal Circuit has gone so far as to proclaim that a permanent injunction is to be the routine, if not mandatory, remedy for patent infringement. See eBay v. MercExchange, LLC, 401 F.3d 1323, 1339 (Fed. Cir. 2005). This proclamation, however, was later rejected by the Supreme Court. See eBay v. MercExchange, 126 S. Ct. 1837 (2006) (holding that patent injunctions are subject to the usual considerations of equitable remedies).

187. For example, copyright is subject to compulsory licensing for "cover" recordings of musical compositions, 17 U.S.C. $\$ 115(2000)$, and for certain statutorily compliant digital transmissions of sound recordings, 17 U.S.C. $\$ 114$ (d)(2). Additionally, many of the user privileges and exemptions in the copyright statute, such as the "fair use" provisions, can be considered compulsory licenses at a zero royalty. See Dan L. Burk, Patenting Speech, 79 TEX. L. REV. 99, 158 (2000). 
these forms of intellectual property may be considered less "strong" than patents, which are largely free of liability regimes.

Second, "strong" property rights tend to be envisioned as relatively clear or bright-line ownership rules, as opposed to fact-specific standards that are muddier. ${ }^{188}$ Clarity or ambiguity as to ownership may arise either in delineating the parameters of the protected subject matter, or in specifying the circumstances under which the right can be invoked. Here again, patents tend to be the paradigm case for strength. Patent law devotes considerable attention to placing the public on notice of the metes and bounds of the protected invention, attempting to spell out the exact character of the protected invention in a detailed document. ${ }^{189}$ Although such written limitations cannot resolve every uncertainty, the boundaries of the patent strive towards the highest degree of clarity that the inherent ambiguities of text allow. ${ }^{190}$ With relatively few exceptions, patent law tends to be equally precise on circumstances that constitute infringement of the patent. ${ }^{191}$ Copyright protection, on the other hand, is subject to a considerable degree of case-by-case muddiness both in determining the bounds of the protected work, and with regard to when exclusivity may be invoked. ${ }^{192}$

Finally, "strong" property rights tend to be conceived as complete rather than divided entitlements, that is, as grants of sole or unitary privilege to exercise the right, rather than as grants under which access to or use of the protected subject matter must be shared. Patent law again constitutes the intellectual property paradigm in this dimension; although patent rights may overlap, each right holder enjoys a complete exclusive right, allowing the holders of overlapping rights to exclude one another - a situation of "blocking" patents. ${ }^{193}$ Patents entail almost no exceptions or exemptions to exclusivity. ${ }^{194}$ Copyright, by contrast, is rid-

188. See Burk, Muddy Rules, supra note 57, at 130-31.

189. 35 U.S.C. $\$ 112$.

190. Which is to say, of course, that ultimately there may still be a great deal of ambiguity in the text. See Burk \& Lemley, supra note 118 , at 33 (noting the unavoidable ambiguities in interpreting patent texts). This is not to say that the ex post interpreter has unfettered discretion in determining the meaning of the patent claims, but simply to acknowledge Northrop Frye's warning that "[readers] are not observers, but participants, and have to guard against not only the illusion of detached objectivity, but its opposite, the counsel of despair that suggests that all reading is narcissism, seeing every text as only a mirror reflecting our own psyches." NORTHROP FRYE, WORDS WITH POWER: BEING A SECOND STUDY OF THE BIBLE AND LITERATURE 75 (1990).

191. See 35 U.S.C. $\$ 271$.

192. For example, the defense of fair use constitutes a classic "standards" based ex post balancing test of circumstantial factors. See 17 U.S.C. $\$ 107$; see also Dan L. Burk, Legal and Technical Standards in Digital Rights Management Technology, 74 FordHAM L. REv. 537, 550 (2005) (discussing fair use as a standard).

193. See Lemley, supra note 69, at 991; Robert Merges, Intellectual Property Rights and Bargaining Breakdown: The Case of Blocking Patents, 62 TENN. L. REV. 75, 81 (1994).

194. The U.S. patent statute contains minor exemptions for compulsory licensing of civilian nuclear devices, 42 U.S.C. $\$ 2183$ (2000), and environmental pollution control, 42 U.S.C. $\S 7608$, as well as exceptions for surgical processes, 35 U.S.C. $\$ 287$ (c), and development of generic drug regulatory data, 35 U.S.C. $\$ 271(\mathrm{e})$. A common law exception for experimental uses of the patented invention 
dled with a vast and confusing array of exemptions and user privileges that allow numerous parties special license to encroach upon the property right under particular circumstances. ${ }^{195}$

\section{B. Beyond Strong Intellectual Property}

These aspects of property strength, particularly as applied to patents, appear consistent with the usage of the "strong property" designator in the prior literature on intellectual property and the firm. The previous literature in fact largely focuses on industries such as biotechnology or small-molecule chemistry where patents are the primary mode of intellectual property protection. ${ }^{196}$ But even though much of the focus in previous analyses has been on patents and trade secrets, we note that the same situation obtains in industries that are highly copyright dependent-not only technological or industrial businesses, such as the software industry, but also in the entertainment industries. Entertainment ventures such as a major theater production or motion picture may be complex, capital intensive, and may involve a large number of specialized production functions. Production of a motion picture may be conceived as a process of coordinating multiple specialized inputs: script writing, musical composition and recording, casting, costuming, cinematography, film and sound editing, sound mixing, special effects, and so on. For a motion picture studio, the choice whether to develop such expertisesuch as casting-in-house or to contract functions-such as special effects - out to a specialty firm, is the Coasean choice. ${ }^{197}$

Property rights in such artistic or entertainment products may also serve to streamline negotiations, although the copyrights that will most often be at issue in these industries have a different property configuration than that of patent. To continue with the motion picture example, a specialty firm that contracts to produce special effects footage faces the classic hold-up problem once it begins to perform: the trading partner may attempt to extort additional concessions after its assets are specifically dedicated to the project. ${ }^{198}$ Copyright confers residual rights in the asset, allowing the specialty firm to redeploy the asset, at least to the ex-

has been historically narrow, and may have been largely obliterated by recent Federal Circuit decisions. See Madey v. Duke, 307 F.3d 1351, 1361 (Fed. Cir. 2002).

195. See, e.g., 17 U.S.C. $\S \S 110-115$ (detailing various statutory exceptions and exemptions to the exclusive rights of copyright holders).

196. See Arora \& Merges, supra note 3, at 456-59; Merges, Intangible Assets, supra note 2, at 19$26,36-45$.

197. However, even taking into consideration the motion picture industry's penchant for narcissistic films about the making of films, see, e.g., TRISTRAM SHANDY: A COCK AND BULL STORY (2005); THE FRENCH LIEUTENANT's WOMAN (1981), we do not anticipate seeing any time soon a major motion picture on the economics of Hollywood entitled Coase's Choice.

198. For an example of exactly such a hold-up situation, see Effects Assocs., Inc. v. Cohen, 908 F.2d 555 (9th Cir. 1990), cert. denied, 498 U.S. 1103 (1991), in which a low-budget horror filmmaker refused to pay as contracted for special effects footage of alien frozen yogurt. 
tent that an asset as specific as special effects footage for a given film can be redeployed. ${ }^{199}$

However, it is important to consider that copyright prohibits only copying, and certain other acts closely related to the disposition of copies of the protected work. ${ }^{200}$ In other words, copyright does not provide rights against the world, only against copyists. Consequently, copyright provides an intermediate form of intellectual property poised between the anti-misappropriation regime of trade secrecy and the exclusionary regime of patent. Copyright is available to rights holders without trade secrecy's burdensome apparatus of nondisclosure agreements and contractual protection, and provides a measure of safety in disclosure. Like patent, it penalizes certain uses of valuable information that has been disclosed to the world. But unlike patent law, copyright law contains a mixture of property and liability rules with numerous exceptions and exemptions, and so does not provide a complete exclusive right. Rather, like trade secrecy, copyright infringement still requires misappropriation, that is, access to and prohibited use of the protected information, before penalties are incurred.

Indeed, much as in trade secrecy, independent development of a substantially similar work is not excluded by copyright. ${ }^{201}$ Additionally, as copyright has increasingly been applied to technical subject matter, courts have adapted the copyright fair use doctrine, which allows users under some conditions to make unauthorized use of all or part of a protected work, into an effective reverse engineering right. ${ }^{202}$ Specifically, courts have repeatedly held that unauthorized intermediate copying may be fair if the purpose is to extract public domain elements from the copied work, and if commercialization of the intermediate copy itself is not the purpose of the reproduction. ${ }^{203}$ This holding has been repeatedly reached to allow, for example, decompilation of copyrighted software for analysis in order to develop interoperable or competing products. ${ }^{204}$

199. See Effects Assocs., 908 F.2d at 559 ("Effects may license, sell, or give away, for nothing its remaining rights in the special effects footage. Those rights may not be particularly valuable, of course ... it remains to be seen whether there's a market for shots featuring great gobs of alien yogurt oozing out of a defunct factory.").

200. Specifically, in addition to the exclusive right to reproduce the work, copyright also confers the exclusive right to adapt the work, to distribute copies of the work, and for certain types of works, the exclusive rights to publicly perform, publicly display, and digitally transmit the work. See 17 U.S.C. $\S 106$.

201. Sheldon v. Metro-Goldwyn Pictures Corp., 81 F.2d 49, 54 (2d Cir. 1936).

202. Sony Computer Entm't v. Connectix Corp., 203 F.3d 596, 602-03 (9th Cir. 2000); Sega Enters. Ltd. v. Accolade, Inc., 977 F.2d 1510, 1513-17 (9th Cir. 1993); Atari Games Corp. v. Nintendo of Am. Inc., 975 F.2d 832, 844 (Fed. Cir. 1992).

203. See Dennis S. Karjala, Copyright Protection of Computer Documents, Reverse Engineering, and Professor Miller, 19 U. DAYTON L. REV. 975, 993 (1994); J. H. Reichman, Design Protection and the New Technologies: The United States Experience in Transnational Perspective, 19 U. BALT. L. REV. 6, 143-44 (1989).

204. Sony, 203 F.3d at 599-601; Sega, 977 F.2d at 1514-15; Atari, 975 F.2d at 835-37. 
Thus, each of the permissible routes for permissible appropriation of a trade secret is available in copyright law as well.

In this regard, it is interesting to note that copyright is the form of intellectual property most compatible with parallel trade secrecy. Whereas the patent applicant must make an election, choosing between maintaining the invention as a trade secret or disclosing it to the public in return for patent protection, owners of copyright need not make such an election. Copyright attaches at the moment that the original, intellectual work is fixed in a tangible medium of expression, regardless of whether the work is ever published. ${ }^{205}$ Indeed, unpublished works may receive some additional protective consideration under copyright, as the choice of when to release the work to the public is an important right to be reserved to the copyright holder. ${ }^{206}$ Copyright thus creates some degree of incentive for disclosure, but can operate in situations where appropriability concerns militate in favor of confidentiality. In other words, copyright occupies an intermediate position between the disclosure regime of patent exclusivity and the misappropriation regime of trade secrecy.

This intermediate position is underscored by the evidentiary structure of copyright. To show that impermissible copying has occurred, copyright holders must prove both an actual physical act of copying, and also that the copying took legally protected content. ${ }^{207}$ Although the former element might be shown by direct evidence, such evidence is rare. Thus, actual copying is instead frequently shown by circumstantial evidence: evidence of access to the work that would have allowed copying, and similarities between the protected work and the allegedly infringing work that would allow an inference of copying. In some cases, the similarities between the two works can be so striking or surprising that access is presumed. But because both independent development-that is, creation of a similar work without actual copying-and reverse engineering that is, actual copying that took no legally protected content-are permissible under copyright, proof of copyright infringement may be considerably more difficult than it would be under a property regime such as patent. $^{208}$

The practical result in the case of copyright is that publication - that is, public disclosure - of a copyrighted work creates a strong presumption against an accused infringer, but not an insurmountable presumption. The proof required to show the elements of copyright infringement is frequently minimal, but can be rebutted by the accused infringer who is

205. 17 U.S.C. $\$ 102(a)$.

206. See Harper \& Row Publishers, Inc. v. Nation Enters., 471 U.S. 539, 552-53 (1985). Specifically, this consideration is factored in under the fair use analysis, although the copyright statute prevents it from becoming dispositive. See 17 U.S.C. § 107.

207. See 17 U.S.C. $\$ 501$

208. There may of course be considerable, very expensive, wrangling in a patent dispute over the borders of the exclusive right, but with regard to the invention covered by the claims there are effectively no excuses or exemptions to the owner's right. 
sufficiently rigorous in documenting development. ${ }^{209}$ For example, in the software context, potential defendants may document development in such a way as to be able to rebut a claim of actual copying, such as using "clean room techniques" to prove copy-free development. ${ }^{210}$ Thus, copyright effectively shifts the burden of proving permissible use to the accused infringer, and allows independent development of the information at the cost of disproving copying. The presumption favors publication or disclosure of the creative work, but attached to a regime of misappropriation rather than one of full exclusivity.

Copyright protection as well as patent protection, then, encourages disclosure of valuable information, alleviating or solving the information disclosure paradox for licensing as well as for employee mobility. But why then is the subject matter of trade secrecy left at the mercy of high transactions costs? Trade secrets are valuable and frequently critical information to the functioning of firms, and are likely to be among the most firm-specific of intellectual assets-specialized processes, customer lists, business plans, and other information integral to the firm. ${ }^{211}$ To lose a trade secret is often tantamount to losing the firm. Why then do they not receive a strong, or at least stronger, measure of intellectual property protection?

Although there may be doctrinal reasons that trade secrets are not so protected, ${ }^{212}$ we suggest that among the defensible policy reasons for assigning them to a "weak" and costly misappropriation regime is their relationship to transaction costs within and between firms. Trade secrecy covers the broadest and most inchoate subject matter of intellectual assets; as Arora and Merges have pointed out, the confidentiality mechanisms of trade secrecy are expensive in part because these assets are so difficult to define. ${ }^{213}$ This association of trade secrets with relatively inchoate subject matter is, we believe, no accident. Trade secrets tend to

209. See, e.g., Calhoun v. Lillenas Publ'g, 298 F.3d 1228, 1231, 1233-34 (11th Cir. 2002).

210. See Pamela Samuelson et al., A Manifesto Concerning the Legal Protection of Computer Programs, 94 COLUM. L. REV. 2308, 2317-18 n.24 (1994). Even if evidence of independent development is available, though, there is some risk, as in the case of the famous suit against George Harrison by the Chiffons for infringement of their song "He's So Fine." Although Harrison was able to show evidence of independent development of his allegedly infringing song "My Sweet Lord," the jury found infringement on the theory that Harrison had likely heard the Chiffon composition on the radio or elsewhere and subconsciously copied it. See Bright Tunes Music Corp. v. Harrisongs Music, Ltd., 420 F. Supp. 177 (S.D.N.Y. 1976)

211. See RESTATEMENT OF TORTS $\$ 757 \mathrm{cmt}$. b (1939); see also UNIFORM TRADE SECRETS ACT § 1(4) (1985), available at http://www.wipo.int/clea/docs_new/pdf/en/us/us034en.pdf.

212. For example, the Supreme Court has held that the federal constitution requires patentable subject matter to be nonobvious, see Graham v. John Deere Co., 383 U.S. 1 (1966), and copyrightable subject matter to be original, see Feist Publ'ns, Inc. v. Rural Tel. Serv. Co., 499 U.S. 340 (1991). Other valuable information may be covered by trade secrecy to the extent that it does not interfere with the goals of the federal intellectual property system, see Kewanee v. Bicron Corp., 416 U.S. 470 (1974); Bonito Boats, Inc. v. Thunder Craft Boats, Inc., 489 U.S. 141 (1989). But such a recital of doctrine of course begs the question as to why intellectual property protection should be divided up in this fashion.

213. See Arora \& Merges, supra note 3 , at 461,470 . 
encompass not only those knowledge assets most likely to be firmspecific, but also those most likely to be indistinguishable from an employee's general human capital.

There is strong evidence that industries benefit where employers forgo specification and enforcement of trade secrets, allowing employees to move freely between firms in "high velocity" employment markets. ${ }^{214}$ We suggest that trade secrecy is properly risky and costly, as a deterrent to excessive use of a protective mode that hampers employee mobility and is costly to society. Thus, from the standpoint of employee incentive and mobility, trade secrecy is not only the most expensive method of protection, but should properly be the most expensive method of protection, as it is the method including forms of intellectual capital most likely to become commingled or indistinguishable from the skills or knowledge of an employee. And, indeed, much of the burden of trade secret protection stems from legal requirements pushing back against intellectual commingling, prompting the employer to demarcate those intellectual assets considered to be proprietary and firm specific.

Overuse of trade secrecy is also discouraged via the patent system. As a matter of federal policy, the patent system entails significant penalties for using trade secrecy when a patent was available-holders of patentable trade secrets not only lose their opportunity to obtain a patent themselves, ${ }^{215}$ but also may have the secret patented out from under them, as the patent statute will award the patent to a later inventor who applies for a patent on the invention, rewarding the choice to use the patent system. ${ }^{216}$ Inventors who opt for trade secrecy run a significant risk of paying royalties on the secret to a later patentee.

This pushes intellectual property owners toward more exclusive protection whenever possible. These stronger forms of intellectual property protection tend to be associated with more defined and definable assets. Both patent and copyright entail default rules that facilitate segregation of firm-specific assets from employee skills. Patents are directed to subject matter that can meet relatively high standards of definition, ${ }^{217}$ subject to a stringent requirement of written description, ${ }^{218}$ and to demarcation in definite claims. ${ }^{219}$ Failure to adequately describe an invention in a patent specification, or to characterize the invention in sufficiently definite claims, results in an invalid patent. ${ }^{220}$ Such discrete technological entities can typically be segregated from an employee's

214. See Alan Hyde, Working in Silicon Valley: Economic and Legal ANalysis of a High-Velocity Labor Market (2003); ANNALEE SAXANIAN, Regional AdVANTAGE: Culture AND COMPETITION IN SiLICON VALLEY AND ROUTE 128 (1994); see also infra notes 256-57 and accompanying text.

215. 35 U.S.C. $\S 102(\mathrm{~g})(2000)$.

216. See W.L. Gore \& Assocs. Inc. v. Garlock, Inc., 721 F.2d 1540, 1550 (Fed. Cir. 1983).

217. See 35 U.S.C. $\$ 112$.

218. Id.

219. See id.

220. See id. 
general skills. Copyright, too, is directed to relatively discrete works fixed in a tangible medium of expression. ${ }^{221}$ Although copyrightable expression may to some extent be commingled with the reputational capital of the creator, copyright rests on the assumption that the forms of expression are essentially infinite, and even if past expressions of an idea are owned by an assignee, so long as ideas remain unprotected, creators-including employees - will yet have myriad variations in which to express themselves. ${ }^{22}$

Thus, we suggest that the relative expense of employing these various modes of intellectual property protection is at least roughly commensurate with their ratio of cost to benefit in lowering firm transaction costs. And, congruent -with our view, it is important to realize that the provision of patents to resolve Arrow's information disclosure paradox simultaneously resolves another disclosure paradox identified by Richard Stern many years ago. ${ }^{223}$ Patents are classically conceived as a quid pro quo in which the inventor swaps a limited term of protection, about twenty years, for public disclosure of his invention. ${ }^{224}$ But trade secrecy lasts indefinitely, so long as the invention remains secret. Given that a rational inventor would prefer perpetual protection rather than twenty years of protection, inventions that can likely be kept secret for longer than twenty years would never be patented. Indeed, one might expect that the only inventions that would be patented are those that would be reverse engineered or independently discovered in less than twenty years. So why offer twenty years of exclusive rights, and the potential attendant disutility of monopoly pricing, in return for the disclosure of inventions that in due course would be disclosed anyway?

The rationale for offering patents makes greater sense if disclosure for purposes of bargaining is the point of the patent, rather than disclosure to increase public knowledge. Rational trade secret holders might choose to keep their technology as trade secrets in perpetuity unless they hope to license them, and then the very significant impediments to such licensing might make the patent system attractive. Thus, the benefit to the public of offering patents for inventions that might otherwise be kept as trade secrets is the increase in interfirm disclosures and the increase in employee mobility by encouraging disclosure and demarcation of the firm's intellectual assets.

221. Id.

222. The limitations on this assumption are perhaps most problematic where the style of expression by an artist resembles past expression assigned to a former employer, creating a potential infringement under the doctrine of "substantial similarity." See, e.g., Franklin Mint Corp. v. Nat'l Wildlife Art Exch., Inc., 575 F.2d 62 (3d Cir. 1978); Fantasy, Inc. v. Fogerty, 654 F. Supp. 1129 (N.D. Cal. 1987). Courts have properly interpreted and applied this doctrine more loosely in such cases, so as to shield the ability of artists to create future works in a particular individual style.

223. See Stern, supra note 167 , at 958.

224. 35 U.S.C. $\$ 154(a)(2)$. 


\section{Some Additional Aspects of Legal Protection}

We have now considered several examples of how intellectual property affects transaction costs within and between firms, and these examples, displaying the relative strengths and costs of different types of intellectual property, indicate that "strong" intellectual property is not the only game in town. Even though patents are undoubtedly important and desirable in many instances, the operation of other forms of intellectual property such as copyright and trade secrecy can in many other instances serve to facilitate interfirm bargains and secure firm assets. Many aspects of these bodies of law appear crafted to perform such functions, and firms routinely employ them to do so. Naturally, all things being equal, firms will tend to prefer stronger entitlements that are clear, undivided, and exclusive. However, as we have hinted, various forms of market failure, including transaction costs, externalities, anticompetitive effects, or other broader societal interests, may dictate the grant of more limited rights than might follow from the unmitigated self-interest of firms. ${ }^{225}$

In addition to the three aspects of the relative strength of rights discussed so far-property/liability, clear/muddy, complete/divided-there are also several other aspects of intellectual property law that bear upon the adequacy or inadequacy of protection in the context of the firm. A second aspect, closely related to the dimensions of entitlement strength, is the breadth of the entitlement itself. The range of embodiments protected by a given form of intellectual property may be broad or narrow. How close does an alternative invention have to be before it is considered to infringe a patent? How similar must two computer programs be before one is considered to infringe on the other's copyright? The broader the scope of a right, the more valuable that right is to a firm and the more opportunity the firm has to enter into transactions that give others the right to use that entitlement, backed by the threat to sue them for infringing on the right if they try to use the idea without the firm's permission.

A third aspect of protection concerns the ease with which a firm obtains a right in the first place - that is, the ease with which the right is recognized or attained. This dimension is partly a function of the legal circumstances that trigger recognition of the right. For example, copyright and common law trademark protection arise spontaneously-for copyright upon fixation of the work in a tangible medium, ${ }^{226}$ or for trademark in the course of using the mark affixed to goods or services. ${ }^{227}$ Such intellectual property rights entail no additional costs beyond the creative or

225. See supra Section II.B; see also Burk, supra note 47, at 130-32 (discussing the range of possible property constructions dictated by transactional considerations).

226. 17 U.S.C. $\$ 102($ a) (2000).

227. See Restatement (ThiRd) UNFAir COMPETITION $\$ 18$ (1995); 1 J. Thomas McCarthy, TRADEMARKS AND UNFAIR COMPETITION $\$ 3.1$ (4th ed. 1996). 
commercial activity itself. Patent rights and federal trademark registration, on the other hand, require review by a governmental agency, and so are more costly to obtain. ${ }^{228}$ By the same token, this dimension is also a function of the substantive requirements for the right, which would be reviewed by a granting agency, or which would determine the circumstances for protection to commence. How original or useful or novel or nonobvious must an idea be in order to receive protection? The less originality, utility, novelty, or nonobviousness that is required, the more readily firms can acquire intellectual property rights.

A fourth aspect of protection concerns the allocation of intellectual property rights between firms and their employees. If an employee creates, or helps create, a new intellectual property asset, to whom does the law initially assign that right, the employee or the firm? There exist a variety of rules in both intellectual property law and in business organization and agency law that help assign rights between firms and employees. ${ }^{229}$ Although property rights can be transferred by contract from their initial default assignment, such contracts generate exactly the sort of transaction costs of greatest concern under the theory of the firm. Thus, initial defaults become important. The greater proportion of rights that the law assigns to firms rather than employees, the greater the protection of firm intellectual property.

Following from this, a fifth and final aspect of protection concerns the ease of transacting around initial assignments of rights. Firms will transfer rights to intellectual property between themselves, or assign rights as between the firm and individual employees, but what is required for the law to recognize a transfer as valid? How clearly need the parties indicate their assent to the transfer? Who needs to assent? In general, how much costly procedure must a firm go through to achieve a successful transfer of an intellectual property right? Although some of these questions are answered by the law of contract or by business association law, in many cases intellectual property law itself sets requirements for transactions; the copyright statute requires a signed writing to transfer exclusive rights; ${ }^{230}$ patent law incorporates a requirement for assignments. ${ }^{231}$ Law and economic analysis has engaged in a fair degree of consideration of the nature of default rules, but rather less consideration of how parties opt out of any given default rule. ${ }^{232}$ We shall characterize protection of a right as insubstantial if little procedure is required to transfer that right and more substantial if costly procedure is required for transfer.

\footnotetext{
228. See 35 U.S.C. $\$ 111$.

229. See infra Section IV.B.

230. 17 U.S.C. $\$ 204$ (a) (2000).

231. 35 U.S.C. $\$ 261$.

232. The leading analysis of rules affecting how to opt out of default rules is probably still Ian Ayres \& Robert Gertner, Filling Gaps in Incomplete Contract: An Economic Theory of Default Rules, 99 YALE L.J. 87 (1989).
} 
Mindful of these aspects of entitlement strength, breadth, ease, allocation, and transferability, as well as a recognition of the range of possible intellectual property forms, we are prepared to consider an integrated framework regarding the effect of different formulations of intellectual property on the size and structure of the firm.

\section{GOLDILOCKS AND THE FIRM}

Given that intellectual property rights have effects on transaction costs both within firms and between firms, it follows that any provision of property rights will have simultaneous effects within firms as well as between firms. This concept requires reconsideration of the effect of property rights on the comparative cost of markets and hierarchy. Coase's fundamental insight is that firms will choose to integrate or dis-integrate production functions depending upon the relative cost of transactions in the marketplace or in a firm. ${ }^{233}$ Thus, all of the studies reviewed in Part II argue that firms will dis-integrate, and interfirm transactions will be more likely to occur, if the cost of such transactions is lowered by the provision of strong property rights. This insight is correct so far as it goes, but with the caveat that it is true only if strong property rights lower transaction costs relative to the cost of performing the same production functions within a single integrated firm.

But, given the effects that we have shown of intellectual property within the firm, if robust intellectual property protection is implemented, it is quite possible-even probable - that those rights may also have an effect on transaction costs within the firm. As we have shown, intellectual property rights help to secure firm assets and delineate allocation of assets between the firm and its employees, maintaining the firm as a region of low transaction costs. ${ }^{234}$ Thus, if a robust property regime lowers transaction costs inside and outside the firm in relatively the same degree, nothing much will change-transactions that would have remained within the firm in the absence of property rights may still remain within the firm in the presence of property rights because the property rights have also made production within the firm less costly.

\section{A. Interfirm Transactions}

As explored both in the previous literature on intellectual property and the firm and in our discussion of that literature above, robust provision of intellectual property rights can encourage interfirm transactions, in several ways that relate to the various dimensions of adequate property that we have also identified above. First, as predicted by the most traditional justifications of intellectual property, such rights encourage

233. See Coase, supra note 9 , at 394-95.

234. See supra notes 106-64 and accompanying text. 
firms to innovate in the first place. ${ }^{235}$ The firm that innovates may find that other firms have better skills and resources for developing and marketing its idea, but absent intellectual property protection the negotiations run into Arrow's paradox of disclosure. As described by Kitch, Merges, and others, patents can overcome this disclosure paradox. ${ }^{236}$ Intellectual property helps reduce interfirm transaction costs and allows firms to specialize in either innovating or in developing innovations. ${ }^{237}$ As the breadth of protection increases, the innovator becomes more assured that it will be able to prevail in a potential suit against an infringing developer, making this positive effect somewhat stronger.

The fourth and fifth dimensions of the strength of legal protection are probably less relevant for interfirm transactions, but not completely irrelevant. Stronger protection for a firm vis-à-vis its employees may give greater assurance to parties contracting with a firm that the firm, and not its employees, has a legal right to an idea. As for the ease of contracting around a given rights assignment, if it is too easy to contract away a default right, parties risk doing so inadvertently. They may then need to take some care in creating contractual provisions so that they have not inadvertently assigned away rights that they did not intend to assign. This care may entail some costs in drafting contracts. A law that requires somewhat more explicit assignment of rights may thus eliminate some of those costs.

However, unboundedly strong rights may cause problems for interfirm transactions. Most obviously, as to the fifth dimension of strength in protection, if the law makes it very hard to opt out of the initial assignment of rights, then it can become quite costly to agree on assigning rights to someone else. More subtly, even as to the breadth and ease of obtaining rights in the first place, overly strong rights can cause problems. Consider first incentives to create an idea. New ideas often draw upon old ones. With broad scope of rights, a would-be inventor may find herself using many protected ideas, thus having to seek permission from many sources. She will have to transact with parties she would not otherwise have to deal with were the scope of protection more narrow. This entails new bargaining costs, and at some point bargaining may become so costly that it is just not worth it, and the innovation is stopped in its track. This is the anticommons problem that has attracted much attention recently. ${ }^{238}$

235. Note that the incentive to the firm as an entity is not necessarily synonymous with, or even consonant with, the incentives of individuals within a firm to innovate, a topic to which we will turn in Section IV.B.

236. See Arora \& Merges, supra, note 3; Kitch, Nature and Function, supra note 46.

237. See Arora \& Merges, supra note 3; Bar-Gill \& Parchomovsky, supra note 1.

238. See Michael A. Heller \& Rebecca Eisenberg, Can Patents Deter Innovation? The Anticommons in Biomedical Research, 280 SCl. 698 (1998); Michael A. Heller, The Tragedy of the Anticommons: Property in the Transition from Marx to Markets, 111 HARV. L. REV. 621 (1998). This problem occurs frequently in intellectual property, as for example in the case of attempting to clear the rights for multimedia or audiovisual works. See, e.g., Katie Dean, Bleary Days for Eyes on the Prize, WIRED 
Similar problems can occur in contracting to develop an idea. With broad protection, a firm considering entering into an agreement to develop another firm's idea will have to worry that other firms possess rights that will block developments. The firms may need to involve more parties in the agreement, thereby increasing costs. This problem is clear in the discussion of interfirm transactions in the studies promulgated by Merges and by Arora and Merges. ${ }^{239}$ Merges in particular describes a "post-Chandlerian" world, filled with modular, dis-integrated specialty firms, where buyers are not necessarily in contractual privity with specialized producers further up the supply chain, as processes, components or other inputs from more remote producers are added to the product prior to the last supplier in the chain. ${ }^{240} \mathrm{He}$ argues that strong property rights allow these innovative specialty firms to exist because such rights provide protection for innovations that would otherwise be misappropriated in interfirm negotiations. ${ }^{241}$ Because contracts are incomplete, and because many firms in the supply chain will not even be in privity with one another, contracts cannot reliably deter such misappropriation.

But the vision of such modular, successive inputs signals a potential danger attending the development of strong property rights. Where there are many inputs, and strong property rights in each, the potential arises for the creation of a so-called anticommons, that is, a situation where property rights are fragmented or too finely divided, impeding or preventing desirable projects that entail such rights. Merges's "postChandlerian" vision carries the risk of such an anticommons if transaction costs attending the ultimate output product become prohibitive due to the need to negotiate for the right to use each input. ${ }^{242}$

Thus, the property rights that allow specialized firms to proliferate can also pose a problem. Negotiating with multiple firms for inputs is

NEws, Dec. 22, 2004, http://www.wired.com/news/culture/0,66106-1.html. However, Epstein and Kuhlick have argued, somewhat unconvincingly in our estimate, that the anticommons problem is based on faulty analogies to the post-Soviet transition economies in which Heller first identified the problem. Richard A. Epstein \& B. N. Kuhlik, Navigating the Anticommons for Pharmaceutical Patents: Steady the Course on Hatch-Waxman (John M. Olin Law \& Economics, Working Paper No. 209, 2004), available at http://ssrn.com/abstract=536322. Empirical investigation into the potential for an anticommons in the biotechnology industry, which Heller and Eisenberg identified as at risk for development of a patent anticommons, has been mixed. A widely cited ethnographic study found little evidence of such an anticommons, in part because the patents that could create congestion were simply being ignored. J. P. Walsh et al., Effects of Research Tool Patents and Licensing on Biomedical Innovation, in Patents in the KNOWLedge-BASEd ECONOMY 285, 324-28 (Wesley M. Cohen \& Stephen A. Merrill eds., 2003). A later empirical study based on citation analysis found evidence of such an anticommons. Fiona Murray \& Scott Stern, Do Formal Intellectual Property Rights Hinder the Free Flow of Scientific Knowledge? An Empirical Test of the Anti-Commons Hypothesis (Nat'l Bureau of Econ. Research, Working Paper No. 11465, 2005), available at http://www.nber.org/papers/W11465.

239. See Arora \& Merges, supra note 3; Merges, Transactional View, supra note 2.

240. See Merges, Transactional View, supra note 2, at 1507.

241. See generally Merges, Intangible Assets, supra note 2, at 47-48.

242. Merges is certainly aware of this problem, see Arora \& Merges, supra note 3, at 471-72; Merges, Intangible Assets, supra note 2, at 47, if a bit dismissive. See Arora \& Merges, supra note 3, at 452 (downplaying the significance of the anticommons problem). 
costly. Were the specialty firms constituted as divisions of a single integrated firm, access to the technology covered by such patents would be available without licensing negotiations. And if Merges is correct, then absent the protection of patents, small post-Chandlerian firms would become integrated into larger firms precisely to achieve such savings; if the costs of licensing without property rights were prohibitive, the small firms would merge in order to avoid such transaction costs.

Consequently, the availability of patents to small firms imposes a cost, and quite possibly a significant cost, on buyers or licensors of technology. Strong property rights may pose an additional, related problem as well. Firms that, for any of a number of reasons, are reluctant to license patented technology may choose to "invent around" existing patents, producing their own technology that does not fall within the claims of the patent. Indeed, it has been argued that inventing around is an important benefit of the patent system, as a spur to further innovation. ${ }^{243}$ Alternatively, firms that prefer not to license patented technology may seek public domain alternatives not covered by the patent. But in technologies where patents are proliferating, firms that hope to pursue such alternatives may be faced with a welter of multiple overlapping patents what Carl Shapiro has termed a "patent thicket."244 Navigating through such a thicket, steering clear of overlapping claims, may be difficult, costly, or simply impossible.

Arora and Merges argue that the innovative benefits of specialized firms must be taken into account in evaluating the anticommons fragmentation problem. ${ }^{245}$ Although we agree that these factors are the correct ones to consider, we essentially pose the inverse proposition: the anticommons fragmentation problem must be taken into account in evaluating the desirability of specialized firms. Some property rights are good, but more property rights are not necessarily better; property proliferation may create perverse incentives to overspecialize and overtransact. Either excessively strong property rights, or an excessive multiplication of property rights, may lead to excessive outsourcing of production functions that were better integrated into a single firm.

Thus, there can be too much of a good thing. A complete absence of intellectual property protection may make interfirm transactions costly, but very strong protection may also make such transactions costly. This becomes more likely as we consider the likely rates of change in the effects described above. As protection gets stronger, the benefits from protection increase, but probably at a decreasing rate. The greatest gains from exploiting an idea probably come from the closest uses, those that

243. See Yarway Corp. v. Eur-Control USA, Inc. 775 F.2d 268, 277 (Fed. Cir. 1985); State Indus. v. A.O. Smith Corp. 751 F.2d 1226, 1236 (Fed. Cir. 1985).

244. Carl Shapiro, Navigating the Patent Thicket: Cross Licenses, Patent Pools, and Standard Setting, in 1 INNOVATION POLICY AND THE ECONOMY 119, 121 (Adam B. Jaffe et al. eds., 2001)

245. Arora \& Merges, supra note 3, at 471. 
will be protected even with just a modest scope of protection. Added scope brings somewhat added profits, but probably at a decreasing rate. In contrast, the costs from stronger protection probably go up at an increasing rate. As more and more parties have claims over related ideas, the costs of bargaining may increase exponentially, as one must bargain with more and more firms.

This suggests the Goldilocks hypothesis for interfirm transactions: there exists an intermediate level of legal protection of firm intellectual property rights that minimizes the costs of interfirm transactions. As legal protection moves away from this optimal level of protection towards either weaker or stronger protection, the costs of interfirm transactions increase. We note that the optimal level is relative to various nonlegal mechanisms that also affect inter- and intrafirm transactions. Thus, the optimal level of legal protection may vary between industries, between societies, and over time.

Note that one way firms may cope with heightened interfirm transaction costs is to move some transactions within the firm. Thus, suppose that legal protection is weaker than the optimal level. If firms are afraid to reveal ideas to outside would-be developers for fear that they will take the idea without compensation, they may choose to develop the idea internally, avoiding that risk. ${ }^{246}$ Thus, with overly weak protection of rights, more transactions will be done within firms than is the case at the optimal level of protection for interfirm transactions. Alternatively, suppose that legal protection is stronger than the optimal level for interfirm transactions. Here, too, firms may respond by bringing some transactions within one firm. The anticommons problem can be reduced if one firm, rather than many, owns all related property rights. Thus, a firm could choose to buy up those with related rights as a way around the costs of interfirm bargaining. ${ }^{247}$

We have just shown the corollary to the Goldilocks hypothesis for interfirm transactions: taking the costs of intrafirm bargaining as fixed, firm size is at a minimum at the optimal level of legal protection for interfirm transactions, and firm size increases as legal protection either increases or decreases from that point. This corollary incorporates the insights of transaction costs economics and GHM residual property rights theories as applied to intellectual property regimes. But the efficiency of interfirm transactions is not the sole determinant of firm size.

246. This is the key idea of Bar-Gill \& Parchomovsky, supra note 1 . Note that they then face risks and costs from the new internal transactions. We discuss those risks and costs in Section IV.B. For here, we take those costs as fixed and ask how the firm boundary varies with variation in the costs of interfirm transactions.

247. See Arora \& Merges, supra note 3, at 452. 


\section{B. Intrafirm Transactions}

As we have shown above, robust protection of firm intellectual property rights can reduce interfirm transaction costs, but only to a point. Just as the provision of strong property is a mixed blessing for lowering interfirm transaction costs, so it may be for intrafirm costs. In thinking about the effects of intrafirm transactions, we must focus on different parts of the definition of what constitutes adequate, inadequate, or excessive protection of firm intellectual property. Although strength and breadth of the right and ease of asserting the right do still matter in some circumstances, the more important elements here are the default rules for who is assigned a right, employer or employee, and the ease of opting out of those default rules. Strong internal protection of firm property rights involves assigning a wide range of rights in ideas to the firm rather than its member individuals and making it hard for the firm to transfer those rights to its members. ${ }^{248}$

Firms face both coordination and motivational problems in organizing internal production. ${ }^{249}$ Supervisors must direct the action of many different employees in a large firm. Suppose that employees owned the rights to many ideas generated within the firm, and hence their consent was needed to use those ideas within the firm. This could create an anticommons problem within the firm. A broad scope in defining intellectual property could worsen this internal anticommons problem as it does the external anticommons problem. Assigning rights to the firm rather than employees avoids this coordination problem. ${ }^{250}$. Of course, through its employment agreements, the firm could achieve the same result even if the default rule granted rights to employees, but if most firms would want rights in their favor, it avoids the costs of contracting to initially assign rights to them. Moreover, it may be easier to opt out of defaults favoring the firm than out of defaults favoring employees. ${ }^{251}$

For creating and developing many ideas, both individual employees and the firm must commit resources that may not be easily redeployed. Thus, the hold-up problem rears its head. ${ }^{252}$ If the firm's commitment is more vulnerable to hold-up than the commitment of its employees, then that is another reason for assigning rights in favor of the firm.

As for motivation, firm employees, both high-level managers and others, will not necessarily want to single-mindedly pursue the firm's stated objectives. Even where it is more efficient to let the firm exploit a given asset, employees may choose to exploit it for themselves. The firm can try to guard against such self-dealing through, for example, monitoring or compensation schemes, but such protections are themselves

248. See supra notes $106-64$ and accompanying text.

249. See supra notes 9-41 and accompanying text.

250. See Merges, supra note 7 , at 54.

251. See Burk, supra note 4, at 17-18.

252. See supra notes 23-24 and accompanying text. 
costly. ${ }^{253}$ Fiduciary duty law helps firms reduce such behavior. For our purposes, we see fiduciary duty law as making it harder to transfer firm assets, including intellectual property assets, to employees. The problem is especially acute for the managers of large public corporations, who have power over immense resources and do not have shareholders looking closely over their shoulders due to the collective action problems of dispersed shareholders. ${ }^{254}$ This suggests that protection of firm intellectual property from employees should be strongest with respect to top managers. ${ }^{255}$

But here, too, protecting a firm's rights too strongly can cause its own set of problems. Firms want employees to bring effort and creativity to their jobs. If employees have overly crabbed rights over ideas and personal assets they develop at work, they will be less motivated to develop those ideas and assets. ${ }^{256}$ Employees also face a hold-up problem, and overly limited rights for them will worsen that problem for them. Indeed, some employees will decide not to work for a firm at all if their rights are too restricted. It is likely to be the most innovative and entrepreneurial employees who stay away from firms if their rights are too limited. ${ }^{257}$

Of course, if the law goes too far in assigning rights to the firm, a firm can always contract around that assignment. However, strong legal protection can make opting out costly and hard to do. This adds its own set of costs, and can make internal decision making more clumsy and time consuming. It can reduce firm risk taking and lead to overly cautious decisions. Corporate law scholars have long noted the problems of overly strong fiduciary duty protections. ${ }^{258}$

Thus, as with interfirm legal protection, intrafirm protection of firm intellectual property rights can be either too weak or too strong. This suggests the Goldilocks hypothesis for intrafirm transactions: there exists an intermediate level of legal protection of firm intellectual property rights that minimizes the costs of intrafirm transactions. As legal protection moves away from this optimal level of protection towards either weaker or stronger protection, the costs of intrafirm transactions increase. Again, the optimal level may vary depending on a variety of nonlegal factors.

253. See Jensen \& Meckling, supra note 15 , at 308

254. See Brudney \& Clark, supra note 142 , at 1003.

255. See supra notes $159-61$ and accompanying text.

256. See Merges, supra note 7, at 17.

257. On the inhospitability of large, bureaucratic corporations to entrepreneurial individuals, see JOSEPH A. SCHUMPETER, CAPITALISM, SOCIALISM, AND DEMOCRACY 140-41 (3d ed. 1950).

258. See generally STEPHEN M. BAINBRIDGE, CORPORATION LAW AND ECONOMICS 251-69 (2002) (discussing justifications for the business' judgment rule as a limit on the strength of fiduciary duty scrutiny); Frank H. EASTERbrook \& Daniel R. Fischel, The Economic Structure of CORPORATE LAW 91-102 (1991) (same). 
Once again, let us start out at the optimal level of intrafirm legal protection and take the level of interfirm protection as constant. Then we ask how firm size changes as the level of intrafirm legal protection either decreases or increases from the optimal level. As intrafirm protection decreases, employees can more easily exploit firm ideas for their own benefit. The firm can take measures to protect against this, but those measures are costly. Coordinating becomes harder as employees must consent to the firm's use of their ideas. ${ }^{259}$ In response to these higher costs, firms will hire fewer employees. It becomes harder to coordinate and motivate in larger firms, and so firms will respond to the higher costs by choosing to be smaller. Firms will also become smaller as employees more readily leave to exploit ideas that they have learned within the firm. Either way, firm size will be lower than size at the optimal level of intrafirm protection.

Similarly, suppose that intrafirm legal protection increases from the optimal level. Employees are now reluctant to join firms, and require higher compensation to do so. Decision making within the firm becomes more cumbersome, and so firms will not be able to coordinate the decisions of a large number of employees as well. Managers take on less risk, both because entrepreneurial types are scared away and because riskier decisions create more risk of litigation under tough fiduciary duty laws. Companies making less risky decisions grow more slowly. ${ }^{260}$ For all of these reasons, firm size is lower than at the optimal level of intrafirm protection.

We have just shown the corollary to the Goldilocks hypothesis for intrafirm transactions: taking the costs of interfirm bargaining as fixed, firm size is at a maximum at the optimal level of legal protection for intrafirm transactions, and firm size decreases as legal protection either increases or decreases from that point.

\section{Interfirm and Intrafirm Transactions Combined}

The overall level of transaction costs, and hence the amount of innovation and development that will occur, depends on the level of both interfirm and intrafirm transaction costs. The size and boundaries of firms also depends on the interaction of interfirm and intrafirm costs. We thus need to bring together the analysis in Sections A and B.

This requires us to note and clarify an ambiguity in both statements of the Goldilocks hypotheses and corollaries above. The hypotheses state that there is an optimal, intermediate level of interfirm or intrafirm legal protection that minimizes interfirm or intrafirm transaction costs. Each statement of the hypothesis leaves out any statement of the level of

259. See Merges, supra note 7 , at $12-13$.

260. The classic analysis of the link between risk taking, innovation, and firm success and growth is Schumpeter. See SCHUMPETER, supra note 257, at 132. 
the other sort of legal protection, i.e., the interfirm hypothesis leaves out intrafirm protection, and vice versa. A more precise statement of the hypotheses would say that for any given level of intrafirm or interfirm legal protection, there is an optimal, intermediate level of interfirm or intrafirm legal protection. The optimal level for one type of protection may vary with the level of the other type of protection, although that need not be so. We shall see further complications along these lines in this Section and Section D.

In exploring the complications that arise from the effect of intellectual property inside and outside the firm, we necessarily abstract from many factors. The optimal levels of legal protections depend on many factors: technology, skills, natural resources, values, and culture, among other things. These will vary by industry and over time. Thus, the optimal levels of protection will vary by industry and over time as well. Over a long range of time, the law can in turn affect those various factors, and vice versa, so the long-term evolutionary story is quite complex. Later we will touch occasionally, and lightly, on some related topics. We will also assume for the moment that we can vary interfirm and intrafirm legal protection independently of each other. This assumption is wrong, and we will consider the impact of dropping it in Section D. For the moment, we also treat levels of protection as two simple dimensions, one for interfirm protection and one for intrafirm protection. We have already seen that the level of legal protection actually involves a variety of facets, ${ }^{261}$ and later we shall consider some of the implications of the multifaceted nature of such protection.

For now, let us assume that interfirm legal protection can take three levels: the optimal level, too low, and too high. ${ }^{262}$ Assume the same for intrafirm legal protection. Of course, in reality each of these is a continuum, and if we were formally modeling this interaction we would assume continuous levels of protection. However, for our purposes here it is conceptually clearer to divide each into three possible levels.

Assuming for the moment that we can vary interfirm and intrafirm protection independently of each other, with each taking three possible levels, we have nine possible combinations. Table 1 shows these nine possibilities.

261. See supra Part III.

262. This thus ignores the point made at the end of Section IV.B that the optimal level of one type of protection may depend on the level of the other type of protection. 
TABLE 1

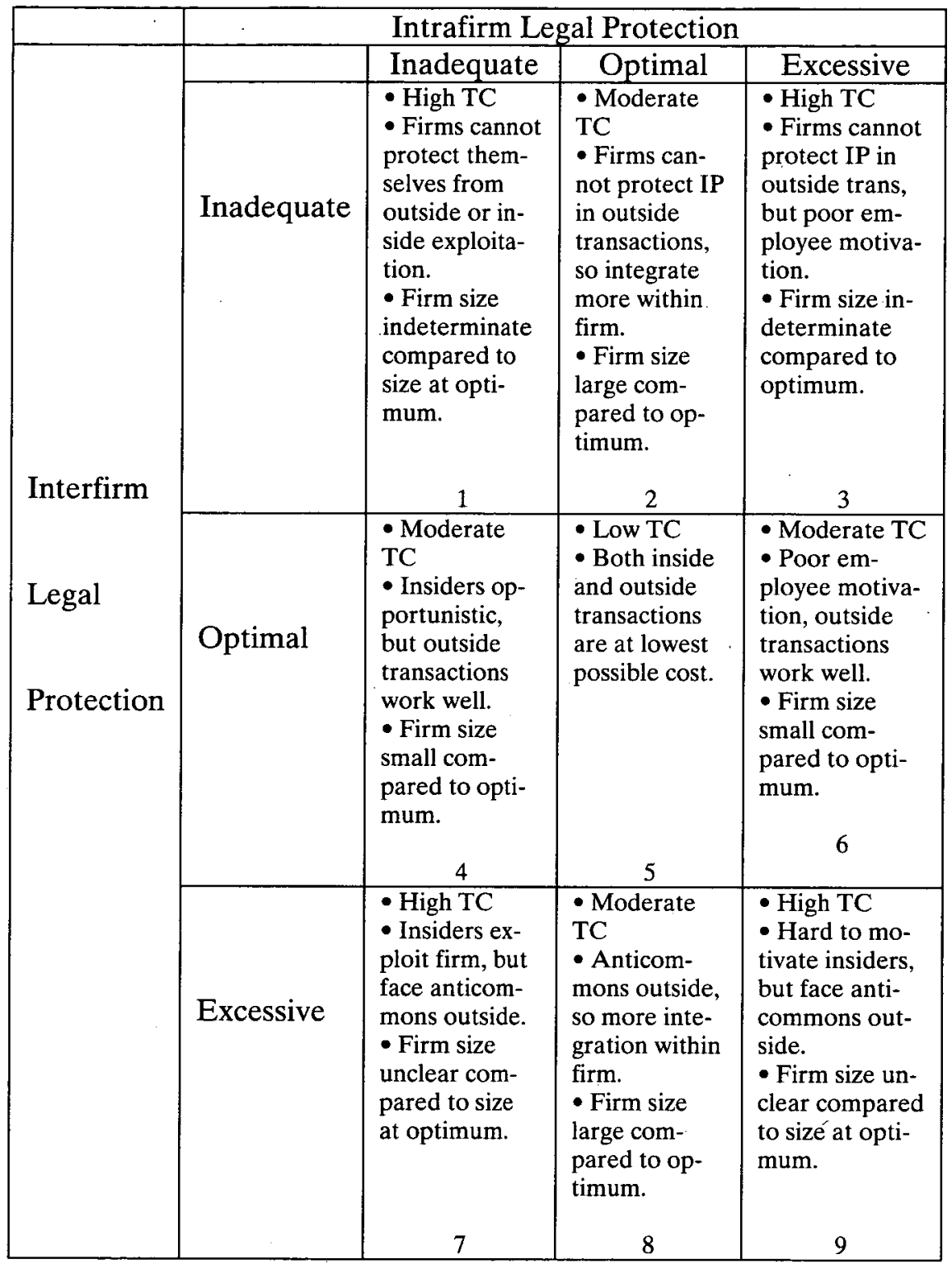

In interpreting this table, let us start with cell 5, where both types of legal protection are at their optimal levels. Here, overall transaction costs are at a minimum. Hence, economic activities are at their most efficient level. We will find robust levels of innovation. Given the costs of interfirm and intrafirm transactions, economic pressures will force a distribution of firms and firm boundaries that economizes on transaction 
costs. ${ }^{263}$ Transactions that can be accomplished at lower cost within a firm will be executed there, otherwise transactions will be executed between firms. We will take firm size and boundary set in this case as a benchmark for the other cases.

Next, let us consider the other two cells in the column that includes cell 5 , i.e., cells 2 and 8 . In these two cells, intrafirm legal protection is at its optimal level, but interfirm protection is not optimal. In cell 2, interfirm protection is too weak. Firms that would like to conduct transactions involving intellectual property with other firms find it hard to protect themselves from exploitation. In response, some choose to conduct some transactions within the firm that would be conducted between firms in cell 5. Thus, firms tend to be larger than at the overall minimum cost level of cell $5 .{ }^{264}$

In cell 8 , interfirm legal protection is now too strong. Firms face the anticommons problem that we have described ${ }^{265}$ hampering the creation and development of new ideas. In response, firms merge to avoid the costs of external transactions. Once again, as with cell 2, some transactions that in cell 5 would be conducted between firms are now executed within a firm. Firm size is again larger than the first best level of cell 5 .

We move on to the other two cells in the row containing cell 5 , i.e., cells 4 and 6 . These are the mirror image of cells 2 and 8 . Here, interfirm legal protection is at its optimal level, but intrafirm legal protection is not. In cell 4 intrafirm legal protection is too weak. Firms here have trouble controlling opportunistic insiders, and may have an internal anticommons problem as individual employee owners of different rights make coordination difficult. In response, firms hire fewer employees, and more specialized firms are formed to handle some transactions that would be handled within one firm in cell 5. Firm size is thus smaller than the first best level of cell $5 .{ }^{266}$

In cell 6 the level of interfirm protection is optimal but intrafirm legal protection is excessive. Employees demand high compensation to work for firms where they will struggle to control assets they helped develop, and decision making is cumbersome and overly risk averse. Firms hire fewer employees and do not grow as quickly. Thus, as in cell 4, firm size is smaller than the first best level of cell $5 .{ }^{267}$

Finally, we have the four corners. In these, both interfirm and intrafirm legal protection are at nonoptimal levels. Transaction costs are at their highest, and innovation at its lowest. Firm size relative to that in cell 5 , the optimal point, is indeterminate. To begin with, consider cell 1.

263. See Coase, supra note 9, at 10-11; see also infra notes $264-67$ and accompanying text.

264. This is the situation that concerns Bar-Gill \& Parchomovsky, supra note 1.

265. See supra notes $245-47$ and accompanying text.

266. See Merges, supra note 7 , at 13-16.

267. This is a concern of many corporate law scholars who frown upon overly strong application of fiduciary duty. See, e.g., BAINBRIDGE, supra note 258; EASTERBROOK \& FISCHEL, supra note 258. 
Here, both sorts of legal protection are inadequate. Employees take advantage of their firms, and yet business with other firms is also risky as the law does not protect a firm's intellectual property from being stolen by its business partners. Firms must choose their poison. Some transactions will just not happen at all, as the costs of executing them either between firms or within the firm are too large. We cannot say whether firms are larger or smaller than at the optimal level of cell 5. It depends on the degree of variation from the optimum for each type of legal protection, among other factors.

In cell 3 , interfirm protection is inadequate and intrafirm protection is excessive. Firms have trouble protecting themselves in transactions with other firms, but if they try to bring transactions within one firm they face hard-to-motivate employees and cumbersome decision making. Once again, whether more or fewer transactions occur within firms than would occur under the conditions of cell 5 depends on the relative magnitude of these two divergences from the optimum.

Cell 7 is the mirror image of cell 3: interfirm protection is excessive and intrafirm protection is inadequate. External transactions face an anticommons problem, but if firms try to internalize that problem by combining into a larger firm they face opportunistic employees and managers who will exploit the assets of that firm. Again, firm size relative to cell 5 depends on the relative magnitude of these effects.

Finally, in cell 9 both types of legal protection are excessive. Firms face an anticommons problem if they do not merge, but employees are reluctant to work in large merged businesses and to work hard for a large merged business, and decision making is cumbersome and costly. The magnitude of these two effects determines whether firms will be larger or smaller than those in cell 5.

The picture that table 1 presents is, of course, highly schematic and simplified. However, we believe that it has considerable suggestive power. Although simplified, it already shows some of the complications that come from considering the interaction between how legal rules related to intellectual property affect the costs of between-firm transactions and within-firm transactions. Even at this point in the analysis, before we add some complications, one can see how both making predictions and making policy suggestions is a delicate task. We must consider the effect of legal rules on both interfirm and intrafirm transactions, and the direction of the effect of varying rules is not monotonic. Transaction costs may fall and then rise as one raises legal protection from a low level. The size of firms may rise and then fall, or vice versa. Determining the optimum level of protection depends on balancing the costs and benefits from several margins of variation. And yet, although the table suggests that the task of analysis is complicated, the table itself is simple enough that we think it helps impose some useful order in thinking through these hard problems. 


\section{Dynamics of Laws That Affect Both}

We now relax one of the assumptions from Section C. There, we assumed that we could vary the interfirm and intrafirm legal protections independently of each other. ${ }^{268}$ That would be so if separate laws set the two different kinds of protection. To a certain degree, that is right. Consider the different dimensions of legal protection that we set out in Part III. The strength and ease of regimes creating intellectual property affect interfirm transactions more strongly than intrafirm transactions, as a look back at Section A will show. The basic rules of patent, copyright, and trade secrecy law, in turn, are the main influence on strength and ease of obtaining intellectual property. In contrast, the division of intellectual property rights between firm and employees and the ease of opting out of default assignments affect mainly intrafirm transactions, as a look back at Section B will show. Specific parts of the law of intellectual property, such as the work for hire doctrine and the shop right, ${ }^{269}$ and parts of fiduciary duty and agency law are the main influence on the division of intellectual property rights and the ease of opting out of default assignments.

However, the effects of these different areas of the law cannot be kept quite so distinct. The scope of intellectual property rights can affect intrafirm transactions too. ${ }^{270}$ In turn, the division of rights between firm and employees can affect interfirm transactions. ${ }^{271}$

These interrelationships complicate our previous analysis. If we think about starting at a given level of legal protection, and ask how moving from that level will affect transaction costs, we must now worry about how the change in law will affect both interfirm and intrafirm transaction costs. However, as long as from any given starting point the direction of the effect for both types of costs is the same, the complication in the analysis does not seem too severe, at least for determining the overall cost-minimizing level of legal protection. If a given move always either lowers or raises both types of transaction costs, the policy implications are unambiguous - move in the direction that lowers both types of costs. The effect on firm size may be ambiguous though. If a given legal change lowers both sets of transaction costs, then whether the change will lead to an expansion or narrowing of firm boundaries will depend on the relative size of the changes in the two sets of costs.

Matters become more complicated still if some changes in legal protection can move transaction costs in different directions. In that case, there may not be any point like cell 5 that simultaneously minimizes both sets of transaction costs. There will still be a point that minimizes overall

268. See supra note 261 and accompanying text.

269. See Burk, supra note 4, at 13-14.

270. See supra note 4 and accompanying text.

271. See supra note 70 and accompanying text. 
transaction costs (the sum of interfirm and intrafirm costs), but that point will not minimize each type of cost.

\section{IMPLICATIONS AND REFINEMENTS}

We have compared and contrasted how different types of laws handle the transfer of intellectual property rights. To this point we have assumed relatively uniform characteristics for technologies subject to intellectual property law. But implicit in much of our discussion is a recognition that technologies vary enormously in their characteristics, such as appropriability. Some technologies will be relatively transparent to an observer, such as some mechanical technologies, requiring no more than a cursory examination by an employee or licensee to understand how they operate. Other technologies will be far more opaque, such as perhaps semiconductor design, requiring extensive explanation and detailed disclosure to understand. The first type of technology is at far greater risk of misappropriation if unprotected by property rights, and can perhaps be carried away in human memory. The second may be more resistant to misappropriation; purloining such information may require the theft of physical documentation, as well as a substantial period of analysis.

This, in turn, implies that different technologies will be more or less prone to confer benefits such as first mover advantages on the developer. Technologies will also differ in the degree of integration with complementary assets that are required for the use of the technology. Thus, nuclear power technologies can exist only within a complex matrix of technical and regulatory inputs; ${ }^{272}$ misappropriated nuclear power know-how is likely unusable without also obtaining all the attendant technical know-how necessary for licensing, fuel procurement, disposal of spent fuel rods, and so on. Certainly, it will be difficult to use such technology in isolation, or for that matter, in secret.

Our analysis therefore suggests that different forms of intellectual property may be optimal for different types of firms in different situations. This conclusion, in turn, suggests the corollary that different forms of intellectual property will predominate in different industries, based upon the practices and characteristics of the industry. We have implicitly assumed such clustering of intellectual property, at least to some degree, in our discussion to this point. In noting the various characteristics of patent, copyright, and trade secrecy, describing their application in different situations, ${ }^{273}$ we are frequently speaking by industry-copyright will be the primary mode of securing firm assets in the motion picture industry, whereas patent will be the primary mode in biotechnology.

272. See generally LANGDON WINNER, THE WhaLE AND THE REACTOR: A SEARCH FOR LiMITS IN AN AGE OF HiGH TECHNOLOGY (1986).

273. See supra notes $1-8$ and accompanying text. 
We have also largely assumed that the forms of intellectual property are monolithic - that there exist relatively uniform characteristics for intellectual property protection within broad classes; patents as a class confer a set of "strong" property rights; trade secrets as a class confer a different set of rights; and so on. But in separate work with Mark Lemley, one of us (Burk) has argued that the different economic profiles of innovation in various industries require industry-specific calibration, or tailoring of intellectual property incentives, and that courts can tailor statutes of general application by means of fact-driven "policy levers" within the statutes. ${ }^{274}$ We suspect that the same is true with regard to reaching the optimal point of transaction costs for various industries, and that such tailoring mechanisms are available within intellectual property statutes. For example, the agency-based determination articulated by the $\mathrm{Su}$ preme Court for the assessment of whether a work is made for hire, is a flexible, multi-factor test that we suspect will vary generally by industry, depending upon the practices or characteristics of the industry. The same applies for the application of fiduciary duty rules. ${ }^{275}$

Given the need and opportunity for such tailoring, there may be competitive pressures in the interjurisdictional market for intellectual property law to develop laws tailored to the needs of specific industries. ${ }^{276}$ Jurisdictions may attract certain businesses by offering intellectual property that best meets the transaction cost profile of that business. ${ }^{277}$ Certainly there is a large literature documenting and analyzing such competition in the development of corporate law. ${ }^{278}$ For this paper we have confined ourselves to the United States, so for the most part there is little opportunity to study interjurisdictional variation. Some of the relevant laws, such as patent, copyright, and federal trademark registration, are set nationally, so there is only one relevant set of laws. Even

274. See Dan L. Burk \& Mark A. Lemley, Policy Levers in Patent Law, 89 VA. L. REv. 1575, 1589 (2003). Other commentators have identified similar incentive policy levers within copyright. See Michael W. Carroll, One for All: The Problem of Uniformity Cost in Intellectual Property Law, 55 AM. U. L. REV. 845 (2006); Joseph P. Liu \& Stacey L. Dogan, Copyright Law and Subject Matter Specificity: The Case of Computer Software, 2 N.Y.U. ANN. SURVEY AM. L. 203. (2005).

275. See generally GEVURTZ, supra note 152, §§ 4.1-.2.

276. See Dan L. Burk, The Market for Digital Piracy, in BORDERS IN CYBERSPACE: INFORMATION POLICY AND THE GLOBAL INFORMATION INFRASTRUCTURE 205 (Brian Kahin \& Charles Nesson eds., 1997).

277. Id. Efforts toward interjurisdictional harmonization of intellectual property offer the benefit of standardization, but dampen the benefits of competitive legal innovation. See Dan L. Burk, Law as a Network Standard, 8 YALE J.L. \& TECH 63 (2005).

278. See, e.g., Roberta Romano, The Genius of American Corporate law 5-6 (1993); Lucian Ayre Bebchuck, Federalism and the Corporation: The Desirable Limits on State Competition in Corporate Law, 105 HARV. L. REV. 1435 (1992); Peter Dodd \& Richard Leftwich, The Market for Corporate Charters; "Unhealthy Competition" Versus Federal Regulation, 53 J. Bus. 259 (1980); Daniel Fischel, The "Race to the Bottom" Revisited: Reflections on Recent Developments in Delaware's Corporation Law, 76 Nw. U. L. REV. 913 (1982); Brett H. McDonnell, Two Cheers for Federalism in Corporate Law, 30 J. CORP. L. 99 (2005); Roberta Romano, Law as a Product: Some Pieces of the Incorporation Puzzle, 1 J.L. ECON. \& ORG. 225 (1985). 
for laws set at the state level, such as agency law, corporate law, and trade secrecy, the basic structure of the law is quite similar across states.

There is at least one interesting exception to the general rule of similarity across states, and it provides an intriguing test-bed for the framework we have developed. That exception concerns how states treat noncompetition agreements between firms and employees. Especially for employees who naturally gather sensitive and important firm-specific information, firms will be concerned that those employees will leave to join a competitor, or found a competitor, and use the information they have learned against their old employer. To protect against this possibility, firms may ask such employees to sign noncompetition agreements that prevent them, upon leaving the firm, from competing against the firm for a specified length of time, in a specified area, for a specified scope of activities. Note that in all states, if firms want to protect against competition by former employees, they must negotiate such agreements; thus, the default rule everywhere, in the United States at least, favors employees on this point. ${ }^{279}$

Where states differ is in the ability of firms and employees to opt out of this default rule. A fully contractarian law would recognize such noncompetition agreements as fully enforceable no matter what their contents, subject only to a requirement that there be adequate indication that both parties indeed agreed to it and that the agreement be specific enough that a court knows when the agreement is being violated. However, American law has not taken such a fully contractarian approach to noncompetition agreements. States differ, though, in how far they stray from a contractarian approach.

The common law treatment of noncompetition agreements, followed in most states, strays only moderately far from contractarianism. It treats such agreements as enforceable as long as they are "reasonable" as to time, geographic range, and scope of activity. ${ }^{280}$ Of course, "reasonable" is the classic weasel word of lawyers, but the accumulation of case law over time has given a decently concrete understanding of how far such agreements can go, and the answer is, decently far.

Some states put tougher limits on noncompetition agreements. Most important is California, which will not treat noncompetition agreements tied to employment agreements as valid at all, no matter how limited their scope. ${ }^{281}$ California thus provides a weaker protection of firm rights than the common law approach; the default rule favors employees in both, but at least firms can opt out of that rule, to a limited extent, under the common law, whereas they are stuck with the rule in California.

279. RESTATEMENT (SECOND) OF AGENCY \& 396 (1958).

280. See RESTATEMENT (SECOND) OF CONTRACT $§ 188$ (1981).

281. See CAL. Bus. \& Prof. Code $§ 16600$ (West 2001). 
Some have hypothesized that this difference in rules helps explain the Silicon Valley phenomenon in California. Scholars have compared high tech firms in Silicon Valley with those in the Route 128 cluster near Boston. ${ }^{282}$ The Massachusetts firms are typically larger and more integrated than the California firms. ${ }^{283}$ Ronald Gilson argues that this is so in part because the California employees can move from firm to firm more easily, without the obstacle of noncompetition agreements. ${ }^{284}$ Thus, employees will start out in one firm, then use what they have learned to found a new firm of their own or work for someone else's start-up.

How does this story fit in with our theory from Part IV? Consider a graph that plots the degree of protection of intrafirm property rights on the horizontal axis and the size of the firm on the vertical axis. The graph will have an inverted U shape, as shown in figures 1 through 3, for reasons described in Part IV; for overly weak protection of firm rights, firms will be small because they cannot protect themselves well enough from employee expropriation, while for overly strong protection of firm rights, firms will be small because employees will be loathe to work for firms in which they are unprotected. ${ }^{285}$

Now, the discussion of Silicon Valley versus Route 128 suggests two stylized facts. First, California lies to the left of Massachusetts on the graph, as the protection of firm rights is weaker in California. Second, Massachusetts lies above California on the graph, as the average firm size is larger in Massachusetts. This leaves three basic possibilities. Figure 1 depicts the first, where both states are to the left of the point where firm size is largest. Figure 2 depicts the second, with Massachusetts at the point of largest firm size and California to the left of that. Figure 3 depicts the third, with California to the left of the point of largest firm size and Massachusetts to the right, but with the curves such that the Massachusetts point is higher than that of California.

282. See HYDE, supra note 214.

283. See SAXANIAN, supra note 214.

284. See Ronald J. Gilson, The Legal Infrastructure of High Technology Industrial Districts: Silicon Valley, Route 128, and Covenants Not to Compete, 74 N.Y.U. L. REV. 575 (1999).

285. See supra Section IV.C. 

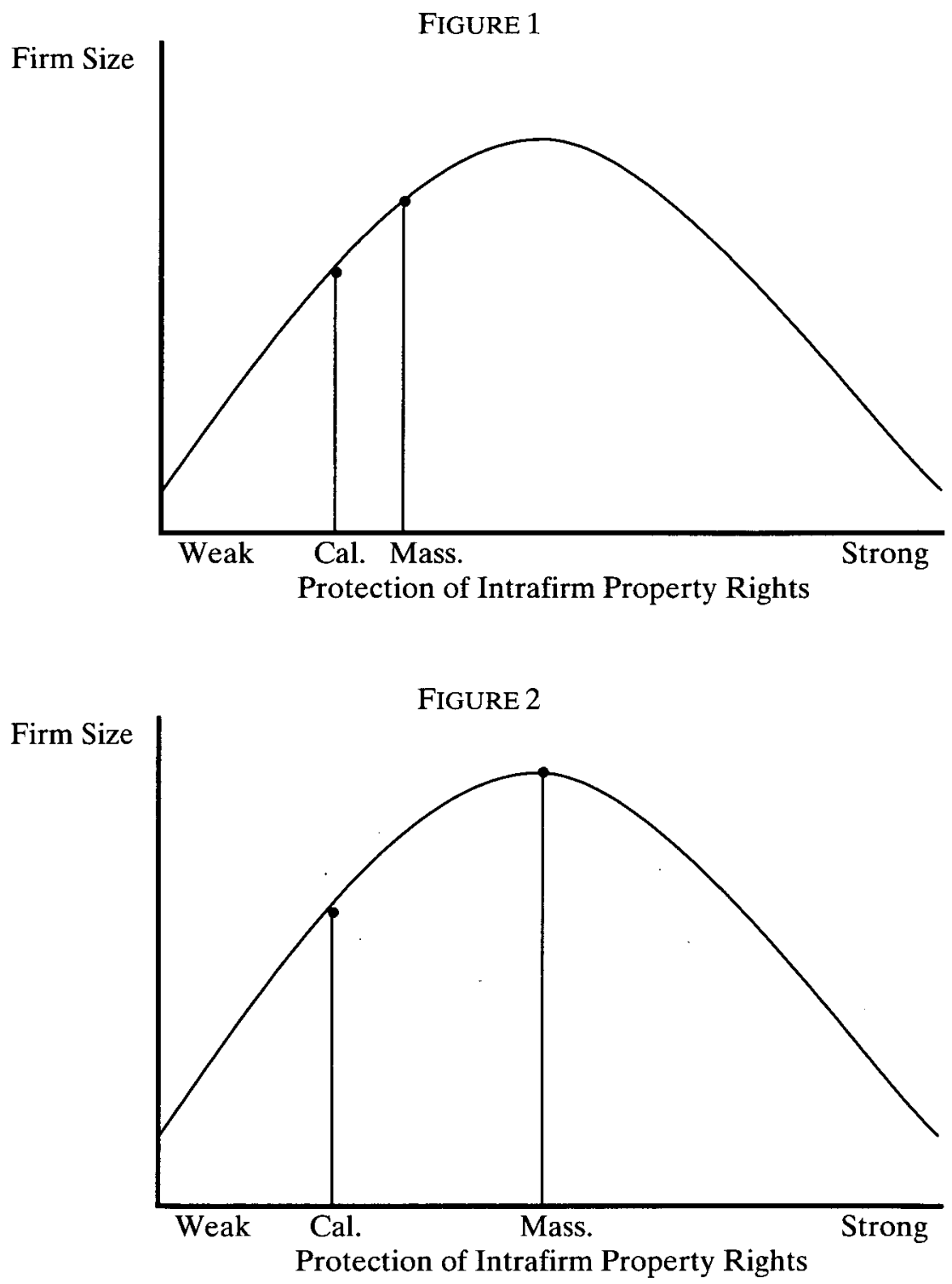


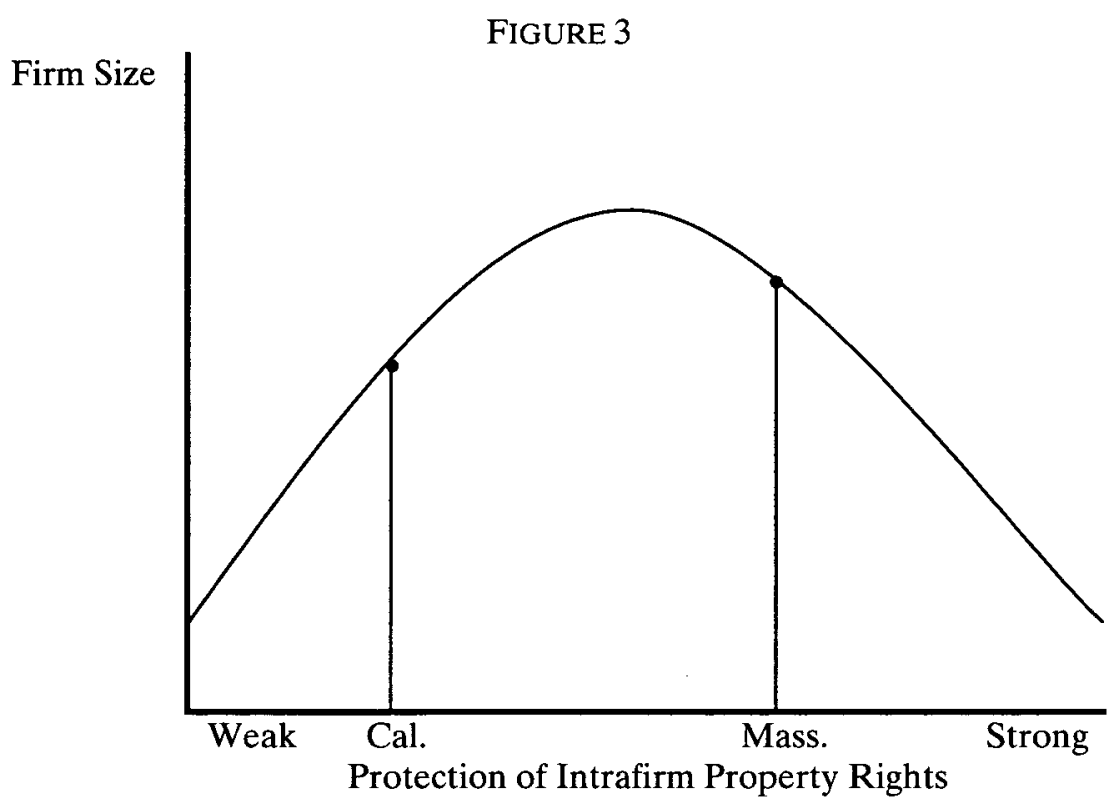

Can we infer anything about the optimality of the laws? If we follow the assumption of Part IV that firm size is greatest at the Goldilocks point where intrafirm protection is optimal, then perhaps yes. In both figures 1 and 2, the Massachusetts law is unambiguously closer to the optimum point than the California law. Figure 3 is more ambiguous, but even there we can say that firm size in Massachusetts is closer to the optimum firm size; whether the law is closer to the optimum law and transaction costs are lower in Massachusetts is less clear without imposing more structure on the theory and obtaining more evidence.

Even as much as we have said here, though, seems to go against the grain of those who praise the California rule as having encouraged more innovation and risk taking. ${ }^{286}$ How does that story differ from our analysis so far? In Part IV we implicitly assumed that market forces push firm size to its socially optimal level given existing law. Thus, firms will be largest where intrafirm protection is at its optimal point, and smaller above and below that point as transacting within the firm is more costly above and below that point. Gilson's story does not seem to accept that assumption. ${ }^{287}$ Rather, there is a wedge between private behavior and the social optimum in his story. ${ }^{288}$ In Massachusetts, firms and their employees contract into noncompetition agreements that discourage new firm formation, hurting society, and hence it is best to curtail their ability

286. See Gilson, supra note 284.

287. See id.

288. See id. 
to enter into such contracts. ${ }^{289}$ Gilson argues there is a market inefficiency due to agglomeration externalities. ${ }^{290}$ Firms collectively benefit from employee mobility, but each individual firm would prefer that its own employees stay put, so there is a collective action problem. ${ }^{291}$ However, our story suggests a further question that Gilson must answer. If noncompetition covenants are inefficient, why don't Massachusetts employees demand higher wages in order to accept them? Our framework suggests that the intrafirm implementation of strong intellectual property rights may tend to hamper employee movement and motivation. In order to attract and retain high quality employees, small firms might have to forgo or de-emphasize intellectual property rights, and indeed there is evidence of such practice in biotechnology. ${ }^{292}$

Still, Gilson's externality story may be right. Thus, it may be possible that for some range of protection, stronger than the cost-minimizing level, firm size is actually larger than the size at the cost-minimizing level; although presumably if legal protection becomes too strong - as, for example, one imagines a mandatory rule that forbids employees from ever competing with old employers anywhere - then the costs to employees will be such that firm size will fall as some employees resist the negative consequences of joining a firm. We remain agnostic as to whether this has indeed happened in Massachusetts; it is quite possible that one of the cases depicted in figures 1 through 3 does accurately describe the two states. However, the possibility does exist, and is an important qualification to our analysis in Part IV.

There may be a simpler way to reconcile Gilson's analysis with ours. The last few paragraphs treat the noncompetition covenant laws as affecting intrafirm legal protection. Perhaps we should instead conceive it as affecting interfirm legal protection. When employees move between firms, they transfer information from one firm to another. Conceived of as affecting interfirm legal protection, Gilson's story fits easily within ours. The situation could be something like that in figure 4; Massachusetts's protection goes beyond the optimal point, with California being at the optimal point. Or California could instead also be to the right of the optimal point, but less so than Massachusetts, or to the left of the optimum, but at a point where the transaction costs are lower than in Massachusetts; we leave those graphs as an exercise for the reader. This treats the Massachusetts rule, and hence the common law rule, as in effect creating an anticommons problem, as firms have too much ability to exploit the information embodied in their employees' human capital, and they face a collective action problem in reconciling their competing rights. ${ }^{293}$

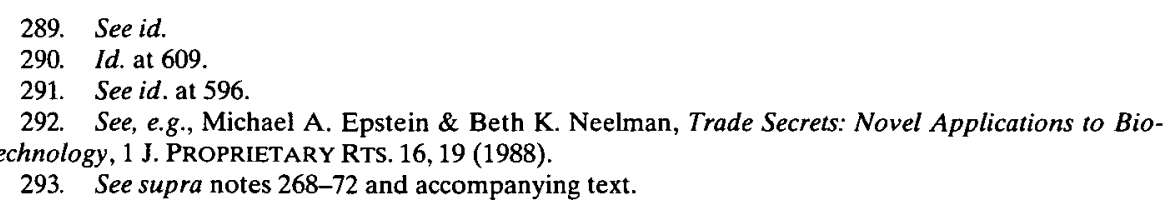


This illustrates the point of Part IV.D-that the same legal rule may affect both interfirm and intrafirm transaction costs.

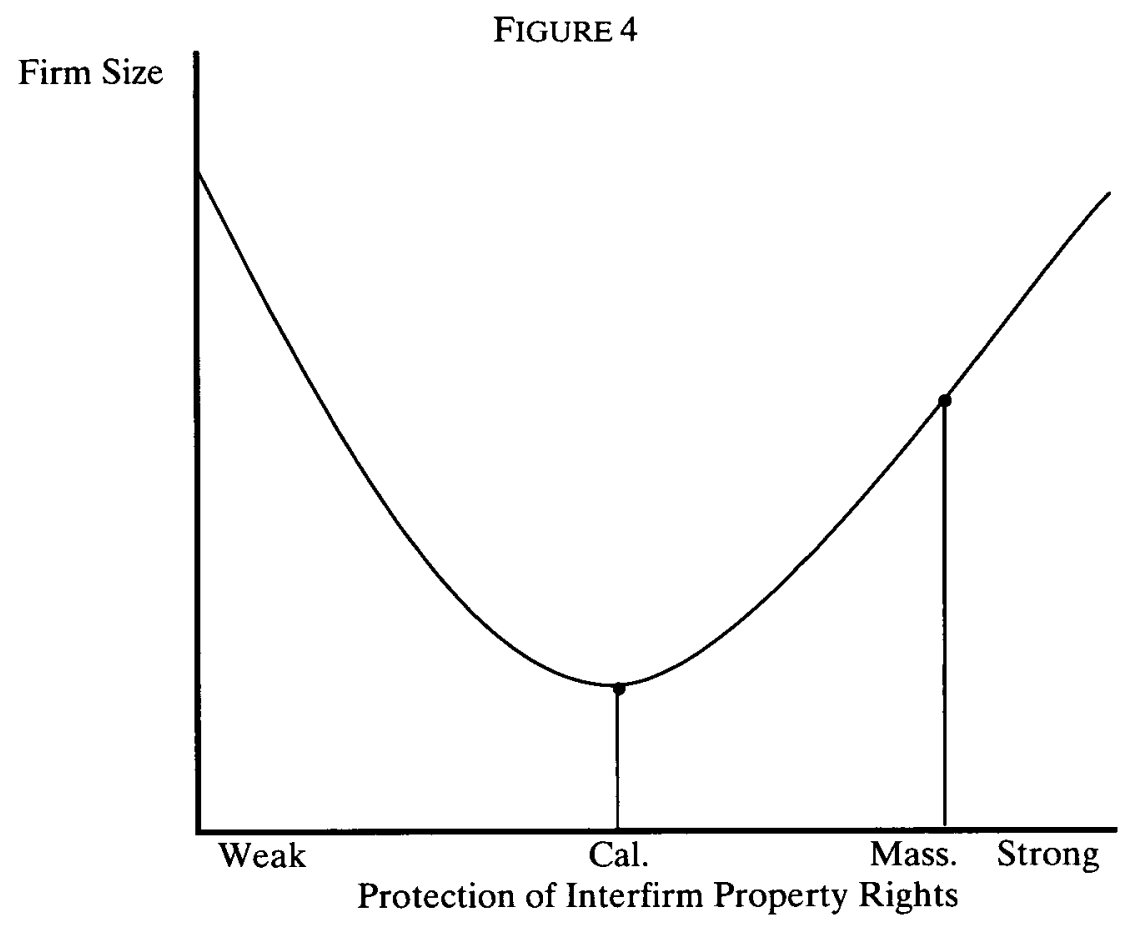

\section{CONCLUSION}

In this article we have attempted to integrate two convergent lines of research regarding intellectual property and the firm-one looking at the effect of intellectual property on transaction costs within the firm and the other looking at the effect of intellectual property rights on transaction costs between firms. We hope to have shown that these discussions are inextricably linked to one another via Coase's germinal theory of the firm, and to have offered a general framework for considering the interaction of these effects. In doing so, we have necessarily recognized the analytical complexity that occurs when internal and external costs intersect at the boundary of the firm; the optimal strength of intellectual property rights vis-à-vis firm transactions is a product of multiple and sometimes elusive factors. The analysis of intellectual property and the firm might have seemed simpler if we were willing to say that the solution is always to provide strong property rights and have faith that everything will then work itself out. ${ }^{294}$ But we suspect that viewing a complex

294. This somewhat fundamentalist article of faith is increasingly common in discussions of intellectual property law. See Mark A. Lemley, Property, Intellectual Property, and Free Riding, 82 TEX. L. 
world in terms of simple rules only works if one is oblivious to much of the world's complexity.

Recognizing such complexity necessarily means that the many variations and ramifications of our framework cannot be fully explored in a single article. There is clearly a great deal of fascinating and valuable territory yet to be charted in considering the role of intellectual property vis-à-vis the theory of the firm. We recognize that this article by no means details all the features of the landscape; our discussion here has been primarily intended to provide a map and locate certain key landmarks for further exploration. For example, in integrating the parallel bodies of literature that have evolved to date regarding intellectual property and the firm, we have followed that literature in focusing primarily on patent and trade secrecy laws as polar opposites, introducing for contrast only a few brief vignettes concerning copyright. But we expect there are yet substantial insights regarding copyright as a firm asset that our sparse discussion has not begun to explicate. Additionally, we have barely noted the presence of trademarks, although this last form of intellectual property is ubiquitous in modern firms and often constitutes the most valuable asset of the firm. We expect trademark law to provide a fruitful area for additional research.

Moreover, our project here has been primarily descriptive, rather than normative. We have discussed the role of intellectual property within the theory of the firm and have noted certain congruencies between those expectations and the features of intellectual property and business association law as currently constituted. We expect that many such congruencies may have developed in response to the explicit or implicit needs of the marketplace. But we recognize that-with apologies to Justice Holmes - the path of the law is neither entirely logic, nor yet entirely experience, ${ }^{295}$ but a combination of anomalous factors including opportunism, market failure, path dependence, and rent seeking, all of which may have introduced into intellectual property and business association law distortions that are contrary to the needs of the firm. ${ }^{296}$ A further, rich area of research will likely be to identify and propose corrections to such distortions.

Indeed, it is even possible that the law rather pervasively and systematically provides too little protection for employees vis-à-vis firms. In transactions that involve inchoate firm-specific assets embodied in employees' human capital, both firms and employees face a hold-up prob-

REV. 1031, 1032 (2005) (discussing the trend toward excessive propertization of intangibles); see also Burk, supra note 187, at 125-26, 132-36 (noting a similar trend toward propertization). See generally Lemley, supra note 70 (same).

295. Oliver Wendell holmes, The Common Law 5 (Harvard Univ. Press 1963) (1881); see also Oliver Wendell Holmes, The Path of the Law, 10 HARV. L. REV. 457, 469-74 (1897) (discussing the primacy of "tradition" over logic in law).

296. See Jessica D. Litman, Copyright, Compromise, and Legislative History, 72 CORNELL L. REV. 857, 896-903 (1987) (detailing rent-seeking behaviors in the enactment of copyright legislation). 
lem. We have seen why the law might best assign rights to firms in such circumstances. However, this leaves employees open to exploitation, so that the opposite assignment might be better. Even if assigning rights to the firm is best, it is possible that protection of employees then requires assigning more power to employees within firms than we observe. ${ }^{297}$ This may be becoming increasingly true as knowledge employees become a more important part of many firms. ${ }^{298}$

Another area ripe for future research is a comparative exploration of the issues discussed here across different countries and legal systems. Additionally, sector-specific studies, particularly empirical studies, may also prove a fruitful avenue of future research. Certain industries offer econometric profiles that may display the effects we describe. For example, the American biotechnology industry is characterized by a large number of small, research-oriented, dedicated biotechnology companies, or DBCs. Often a patent or cluster of patents are the only assets of such firms. Merges and Arora focus considerable attention on this sector, apparently seeing there evidence of a robust collection of specialized postChandlerian firms. ${ }^{299}$ But few of these firms thrive; they fail at a fairly high rate or are acquired by larger firms. ${ }^{300}$ This rate of failure and acquisition is not especially indicative of efficiency, ${ }^{301}$ and we suspect may, in fact, point to an overabundance of patents, leading to an inefficiently large number of dis-integrated firms. The Goldilocks hypothesis suggests that firms will respond to such inefficient disintegration through reintegration, ${ }^{302}$ i.e., through acquisitions or through the disappearance of some firms, which, as we have just suggested, seems to be the case. Closer examination of the biotechnology industry may reveal that the provision of patents, primarily by way of the federal Bayh-Dole Act, ${ }^{303}$ has passed the "Goldilocks" point for optimal firm size.

Similarly intriguing questions are suggested by the recent shift in patenting practice in the computer software industry. For a variety of practical and historical reasons, the last quarter of the twentieth century saw software primarily reliant upon copyright for intellectual property protection. But over the past decade or so, as courts and the Patent Office have become more amenable to software patent claims, the industry

297. See Brett H. McDonnell, Employee Primacy, or Economics Meets Civic Republicanism at Work (Minn. Legal Studies Research Paper No. 06-06), available at http://ssrn.com/abstract=878790.

298. See A Survey of the Company: The New Organisation, ECONOMIST, Jan. 21, 2006, at 3-5.

299. See Arora \& Merges, supra note 3, at 451.

300. See Ashish Arora \& Alfonso Gambardella, Complementarity and External Linkages: The Strategies of the Large Firms in Biotechnology, 38 J. INDUS. ECON. 361, 365 (1990).

301. Iain M. Cockburn, Blurred Boundaries: Tensions Between Open Scientific Resources and Commercial Exploitation of Knowledge in Biomedical Research 9, 12 (Apr. 30, 2005), http://people. bu.edu/cockburn/cockburn-blurred-boundaries.pdf.

302. See supra notes 7-8 and accompanying text.

303. Pub. L. No. 96-517, $\$ \$ 200-211,94$ Stat. 3015, 3019-29 (codified as amended at 35 U.S.C. $\S \S 200-211)$. For additional criticisms of Bayh-Dole, see Arti K. Rai \& Rebecca S. Eisenberg, BayhDole Reform and the Progress of Biomedicine, 66 L. \& CONTEMP. PROBS. 289 (2003). 
has become increasingly reliant upon patents rather than copyrights for protection. This change from a weaker to a stronger form of intellectual property protection may also have implications for the optimal size and structure of software firms. Such industry case studies, together with further theoretical exploration, will be important to defining the points at which rights are neither too sparse, nor too extravagant, but "just right" for the intrafirm and interfirm purposes of intellectual property. 